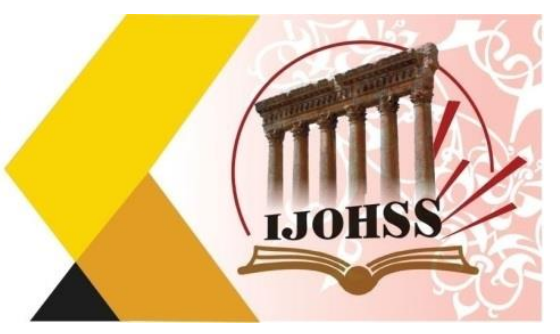

\title{
الجريمة المنظمَّة عبر الحدود وعلاقتها بجرائم الأعمال المالية والتجارية الماية \\ (دراسة مقارنة)
}

\author{
د. محمود أحمد حسين الجنابي \\ قسم القانون - كلية السلام الجامعة الجنة \\ العراق الق العال
}

الجريمة مرضص خطير يتفاقم في المجتمع ، وهو مرض مزمد من بطارد الإنسان منذ وجوده وتنتوعت أشنكاله

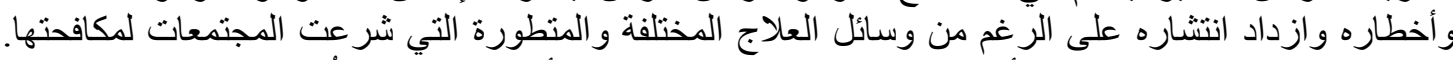

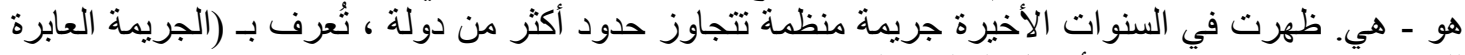
للحدود) ، و علاقتها بجر ائم الأعمال المالية والت التجارية.

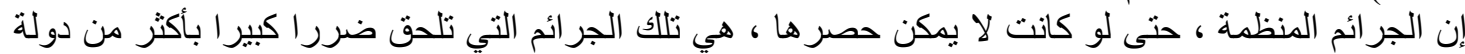

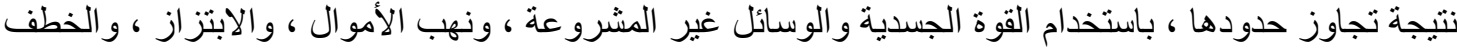

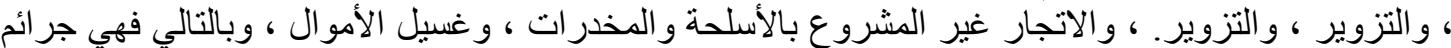

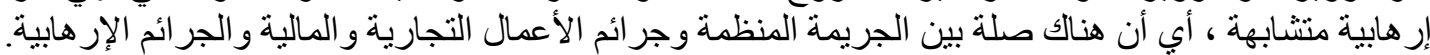

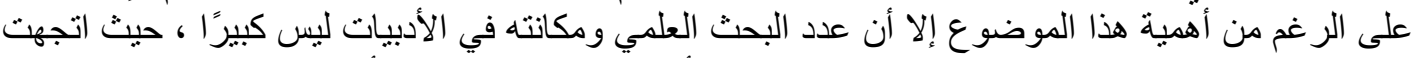

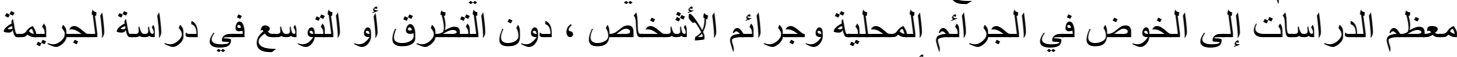

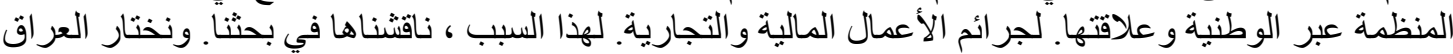

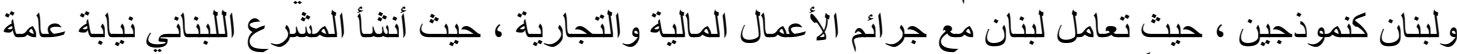

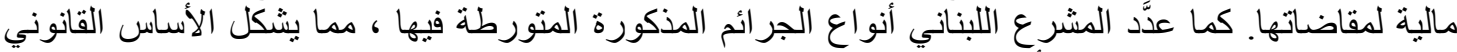

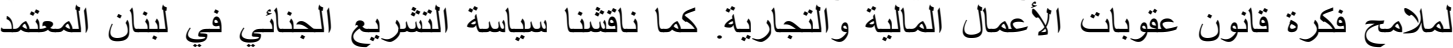

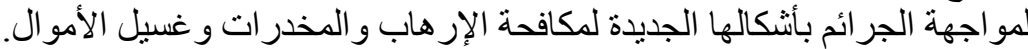

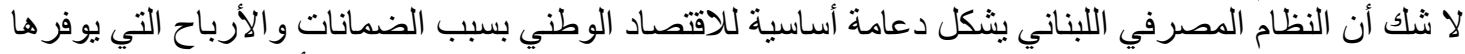

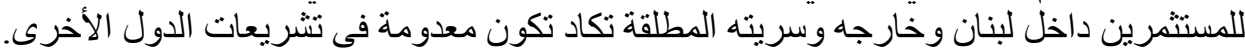

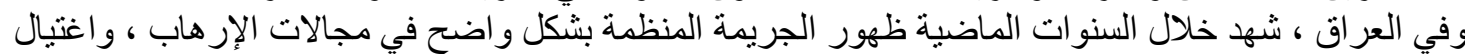

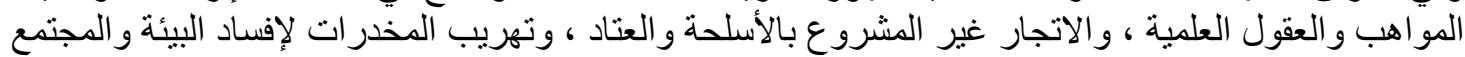

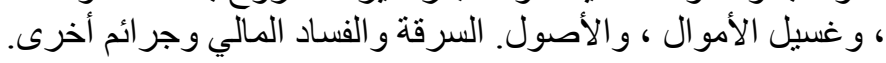

$$
\text { الكلمات المفتاحية: الجريمة المنظَّمة، جرائم الأعمال. }
$$




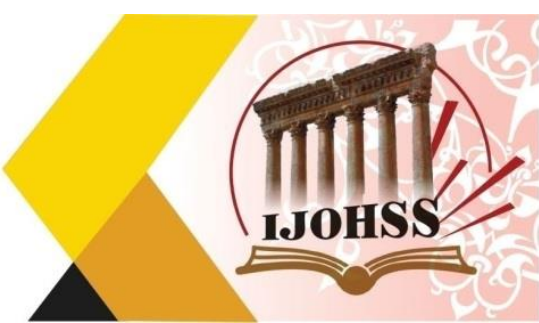

\title{
Cross-Border Organized Crime and its Relationship to Financial and Commercial Business Crimes (A comparative study)
}

\author{
Dr. Mahmoud Ahmed Hussein Al Janabi \\ Law Department - University College of Al-Salam \\ Iraq
}

\begin{abstract}
Crime is a serious malady that aggravating in society, and this is a chronic malady that has haunted human being since his existence and its forms and dangers have diversified and its spread has increased despite the various and advanced means of treatment that societies have legislated to combat it. In recent years, an organized crime has emerged that crosses the borders of more than one country, known as (Cross-border crime), and its relationship to financial and commercial business crimes. The organized crimes, even it can't be limited but it constitute those crimes that cause great harm to more than one country as a result of transgressing its borders, using physical force and illegal means, looting money, extortion, kidnapping, counterfeiting, forgery, illegal trafficking in weapons and drugs, and money laundering, and it is thus Terrorist crimes are similar, i.e. there is a link between organized crime, financial and commercial business crimes and terrorist crimes. Despite the importance of this subject but the number of scientific research and its placement in the literature is not large, as most studies have tended to delve into local crimes and crimes of persons, without addressing or expanding the study of transnational organized crime and its relationship to financial and commercial business crimes. for this reason, we discussed it in our reaserch. and we choose Irak and Lebanon as examples since Lebanon has dealt with the crimes of financial and commercial business, as the Lebanese legislator established a financial public prosecution for it to prosecute them. The Lebanese legislator also enumerated the types of named crimes involved in it, which constitutes a legal basis for the features of the idea of a financial and commercial business penal law.as well as we discussed the policy of the penal legislation in Lebanon adopted to confront against the crimes in its new forms anti-terror, anti-drug and money laundering. There is no doubt that the Lebanese banking system constitutes a mainstay of the national economy because of the guarantees and profits it provides to investors inside and outside Lebanon and its absolute secrecy almost non-existent in the legislation of other countries and in Iraq, during the past years, he witnessed the emergence of organized crime clearly in the fields of terrorism, assassination of talents and scientific minds, illicit trafficking in weapons and materiel, drug trafficking to corrupt the environment and society, money laundering, asset theft, financial corruption and other crimes.
\end{abstract}

Keywords: Cross-Border Crime, Business Crimes. 


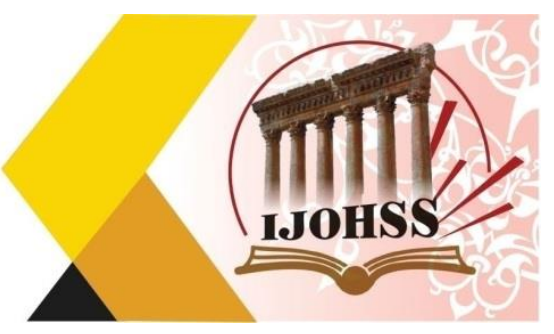

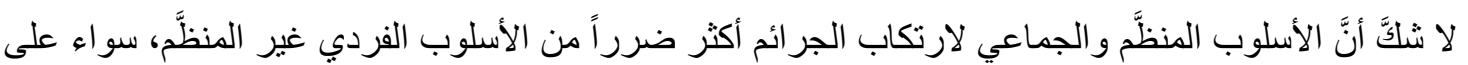

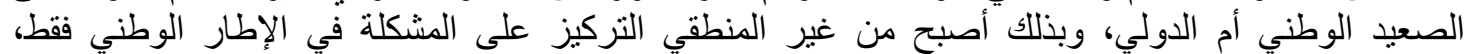

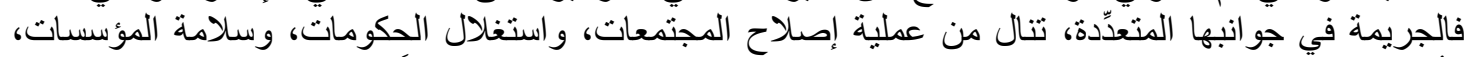

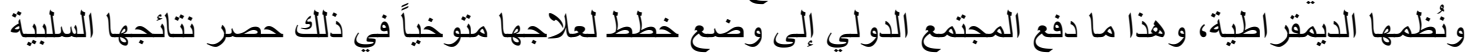

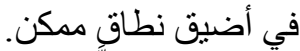

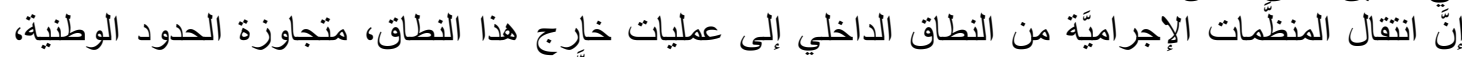

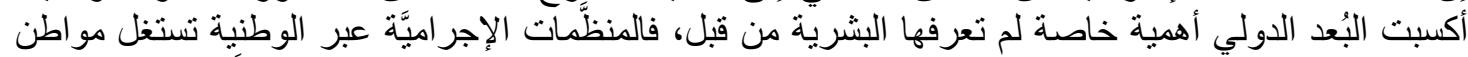

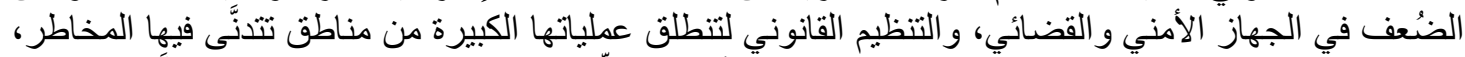

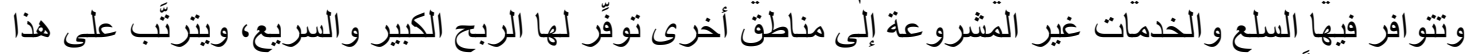

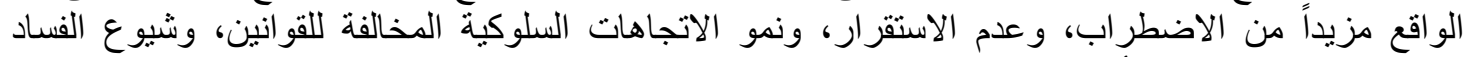

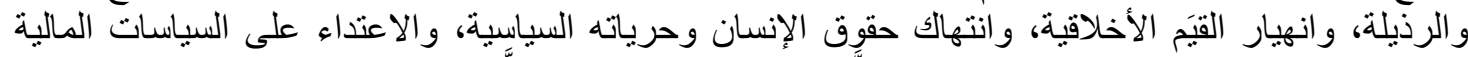

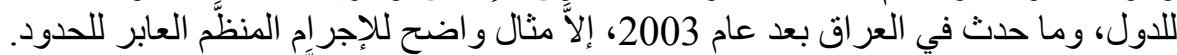

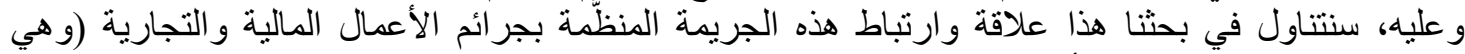

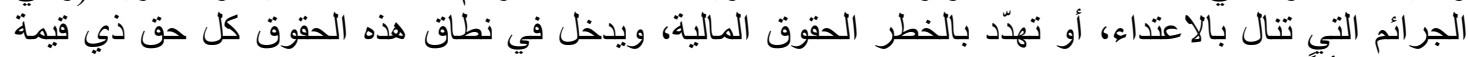

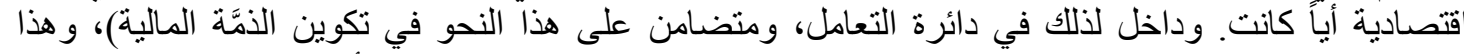

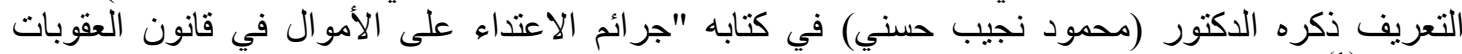

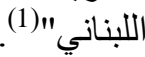

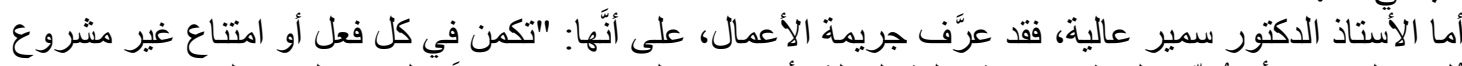

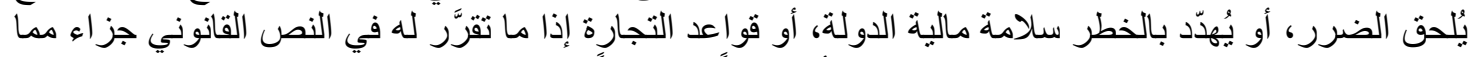

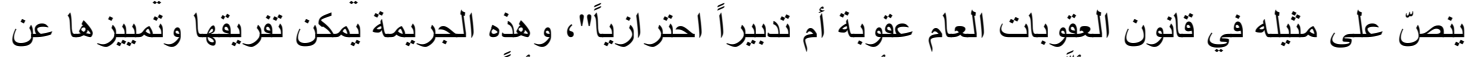

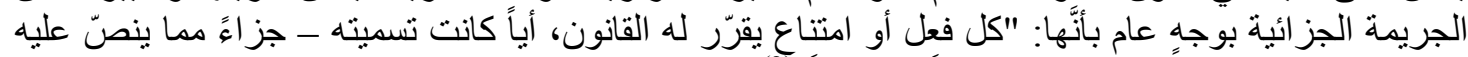

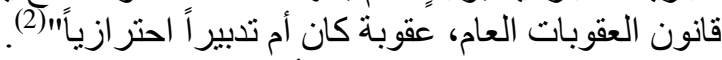

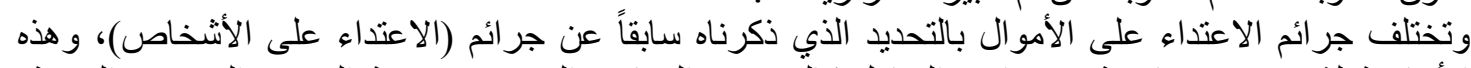

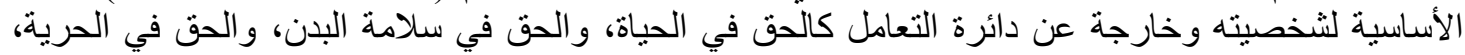

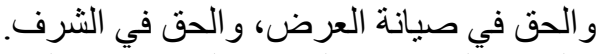

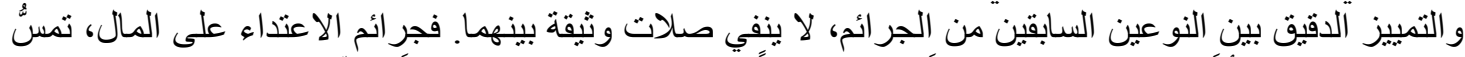

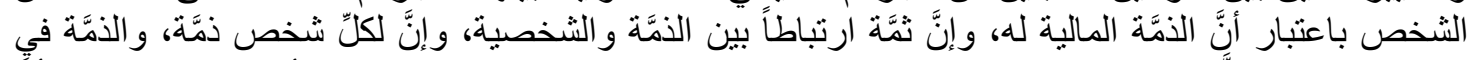

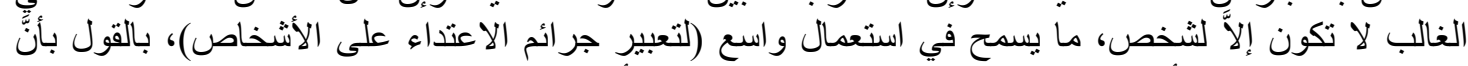

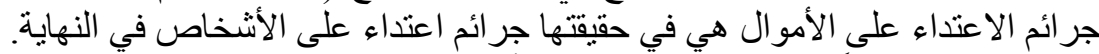

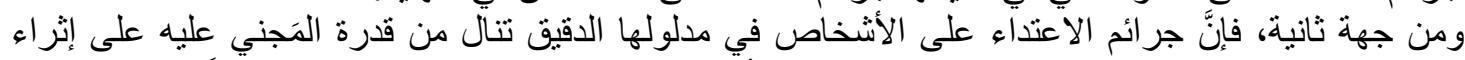

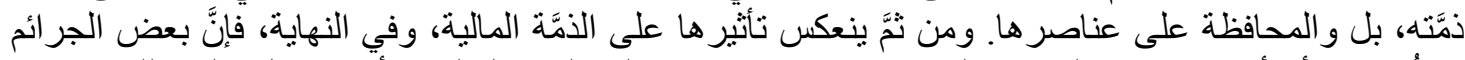

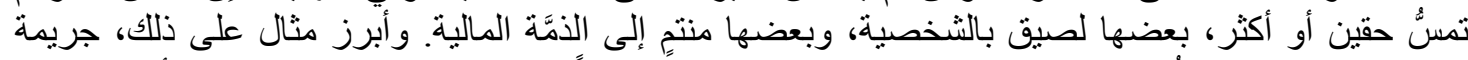

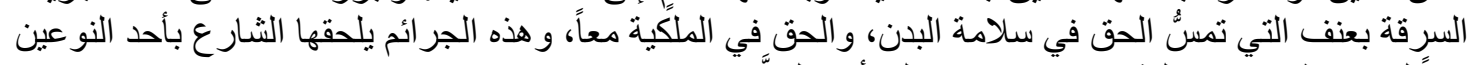
تبعاً لما يستظهره من غلبَة معنى الاعتداء على أحد الحقيَّن.

(الني (الدكتور محمود نجيب)، جرائم الاعتداء على الأموال في القانون اللبناني، (در اسة مقارنة)، الطبعة الأولى، دار

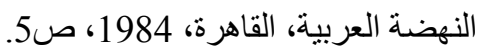

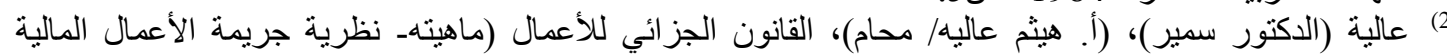
و التجارية)، (در اسة مقاربة)، الطبعة الأولى، (مجد) المؤسسة الجامعية للار اسات و النشر و التوزيع، بيروت، الأنية 2012، 


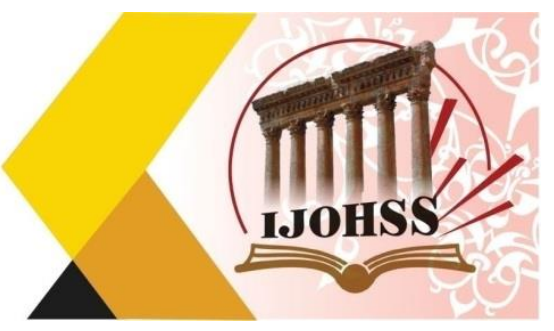

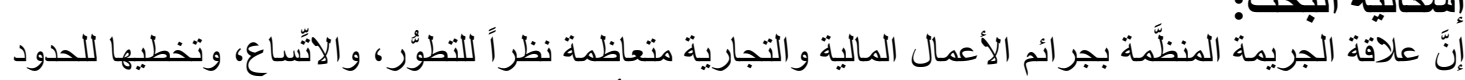

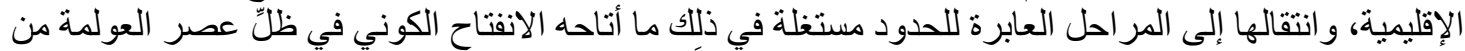

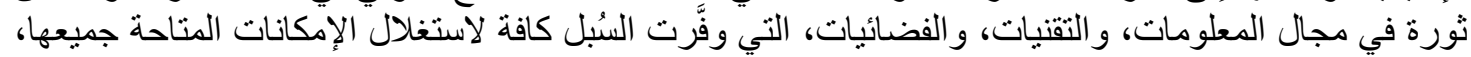

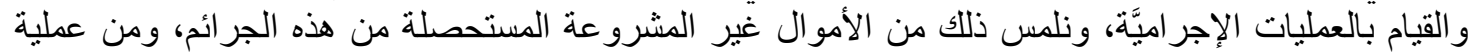

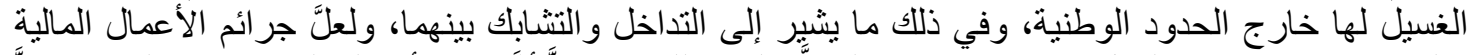

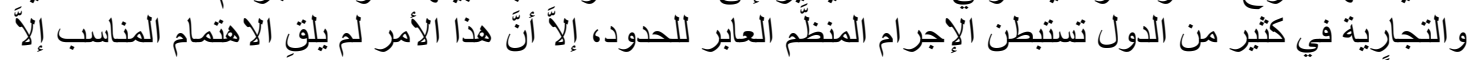

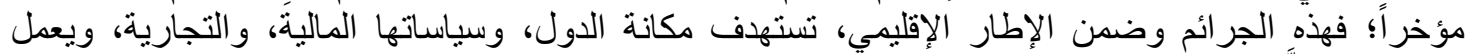

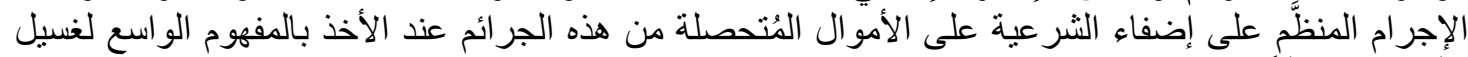

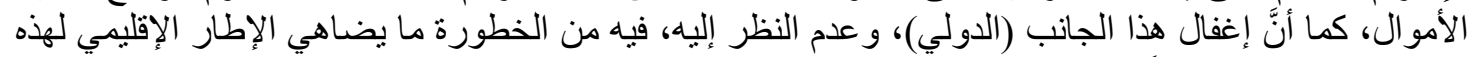

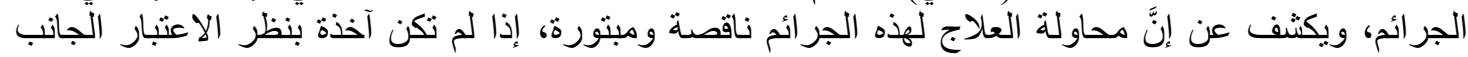
الدولي لهذه الجر ائم.

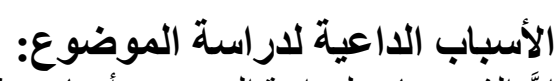

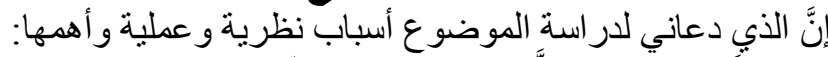

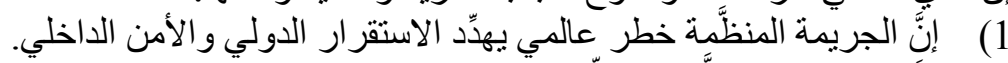

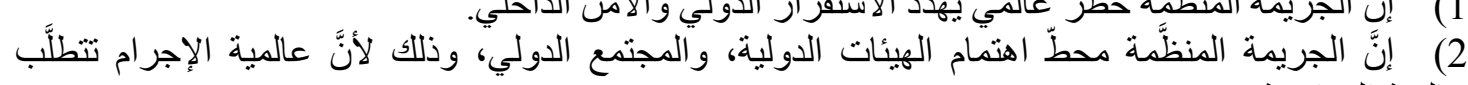
عالمية المو اجهة. 3) "حداثة الاهنمام بهذا الموضوع نسبياً على الصعيد العربي، وحتى على المستوى والصعيد المحلي لكلّ الأقطار العربية.

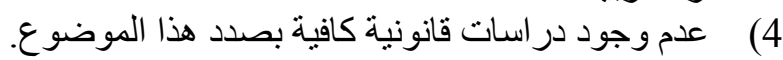

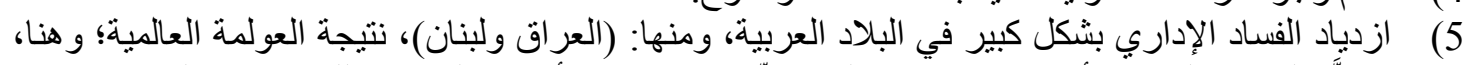

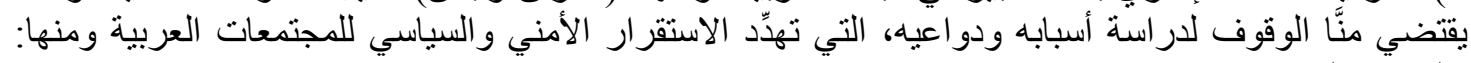

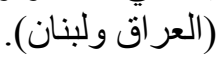

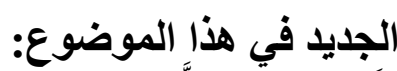

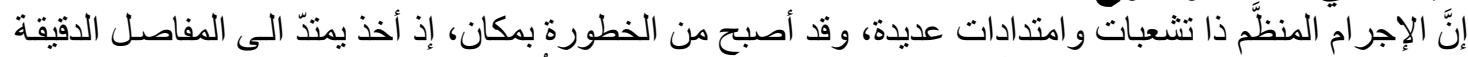

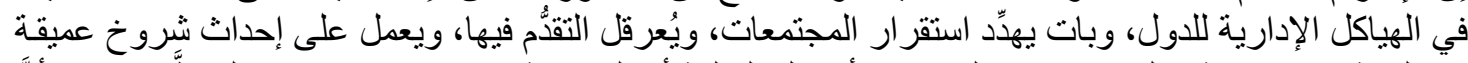

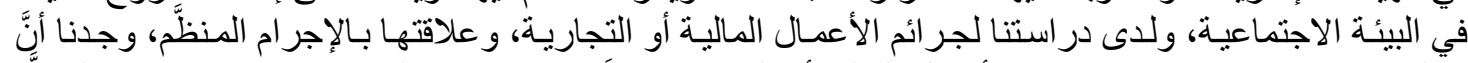

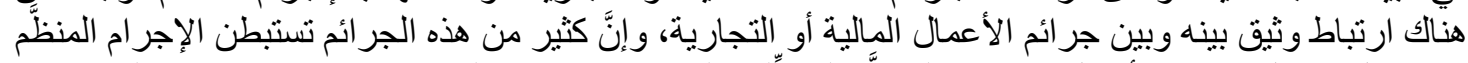

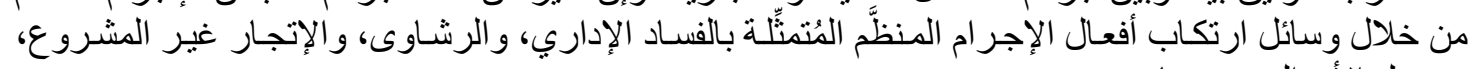
و وغنيل الأمو ال و غير هنائ.

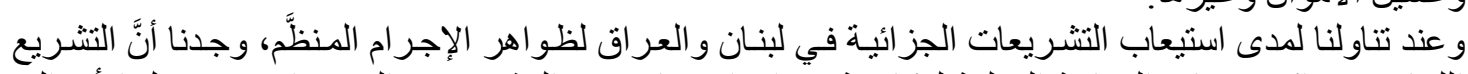

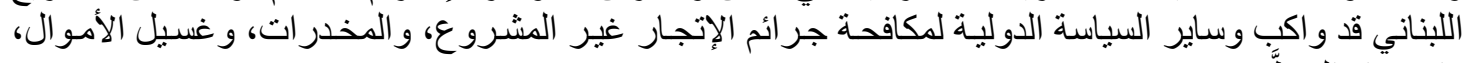

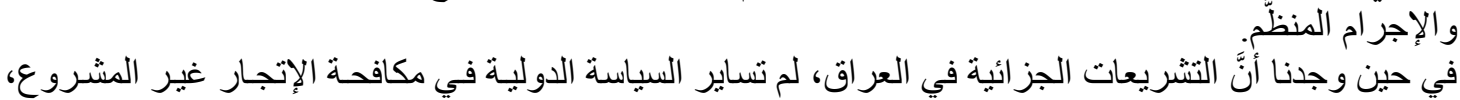

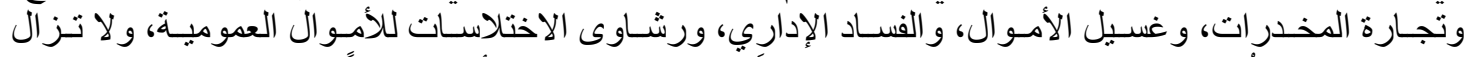

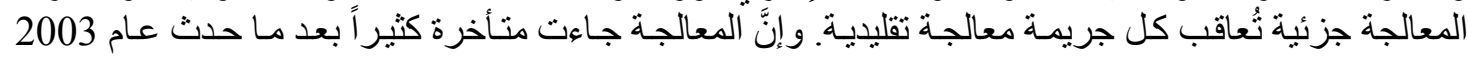
وسقوط الدكتاتورية في العراق.

\section{منهجية الدراسة:}

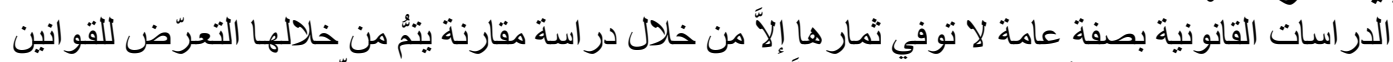

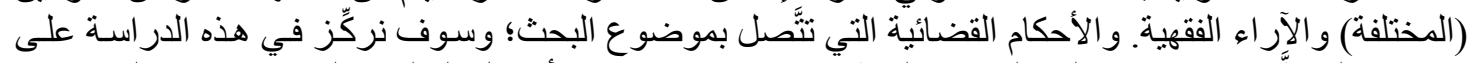

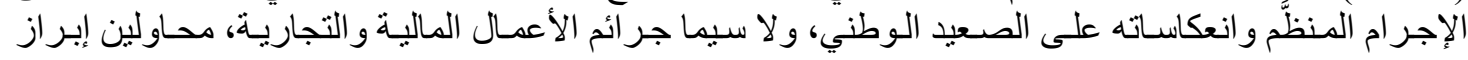




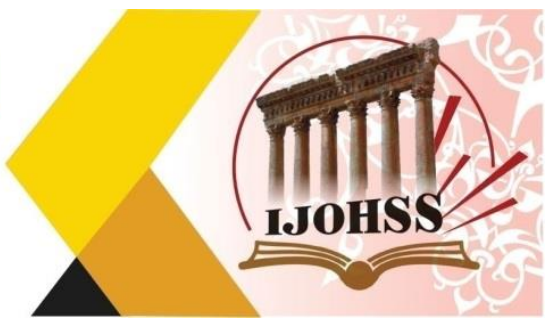

خطورة الجريمة المنظَّمة، واعتبار البُعد الدولي لا يقلّ أهمية عن البُعد الوطني لهذه الجر ائم ومستطلعين موقف

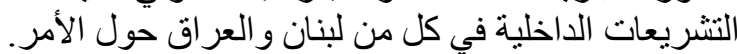

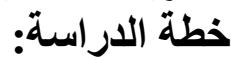
ستكون خطة الدر اسة وفق الآتي:

ماهية الجريمة المنظّمة عبر الأوَّل الوطنية وأركانها

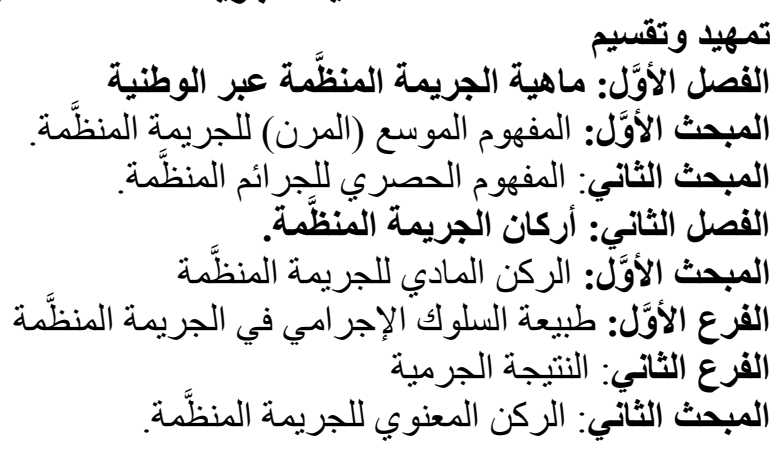

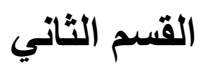 \\ علاقة الجريمة المنظَّمة بجرائم الأعمال المالية والتجارية}

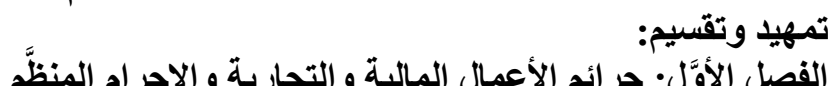

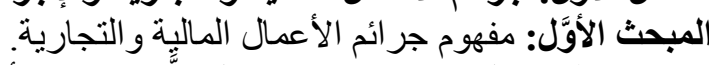

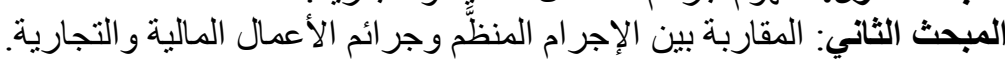

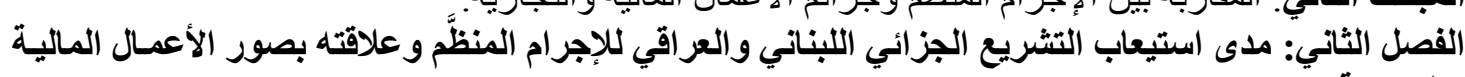
والتجارية. المبحث الأوَّل: استيعابه في التشريع الجز ائي اللبناني. المبحث الثاني: استيعابه في النتشريع الجزائي العر اقئي.

\section{القسم الأوَّل \\ ماهية الجريمة المنظمَّة عبر الوطنية وأركانها}

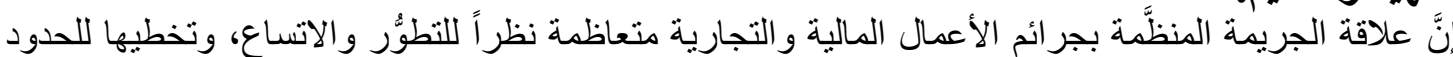

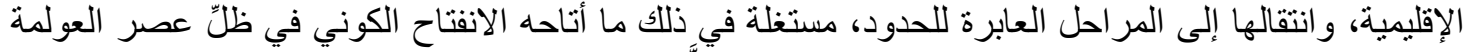

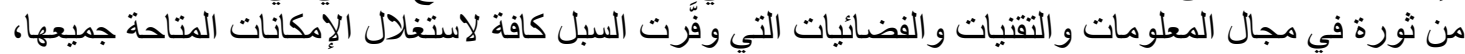

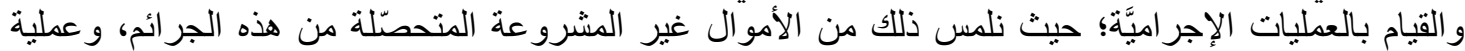

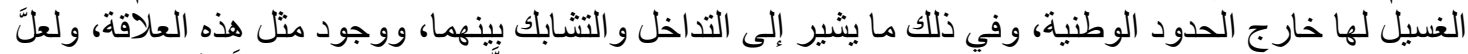

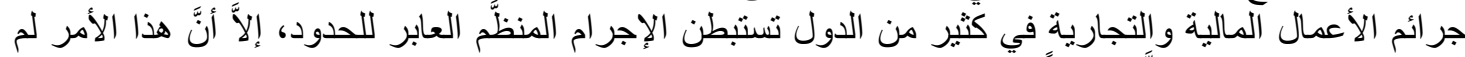

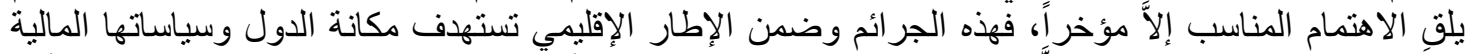

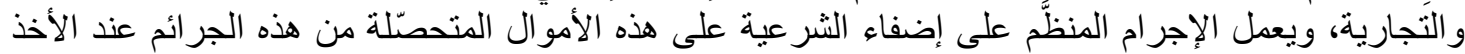

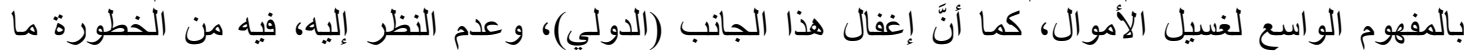




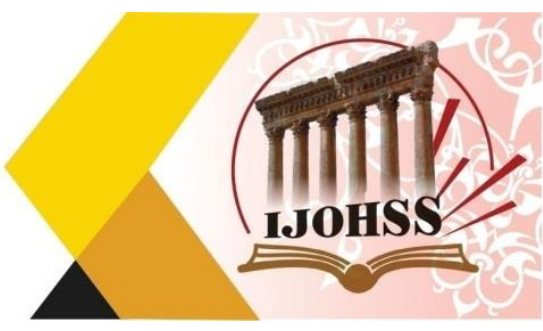

يضاهي الإطار الإقليمي لهذه الجرائم، ويكثف عن إنَّ محاولة العلاج لهذه الجرائم ناقصة ومبتورة، إذا لم تكن

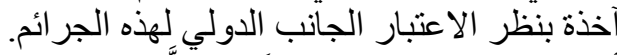

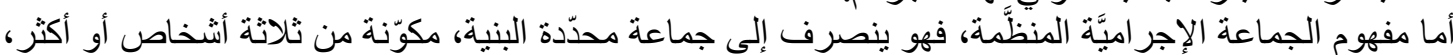

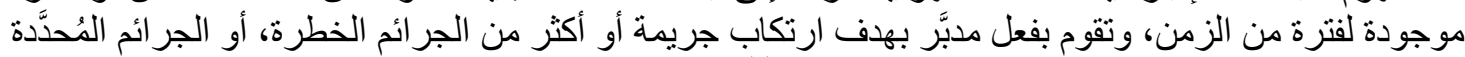
بالاتفاقية، من أجل الحصول عل الزمن ونى منفعة مادية أو مالية (1).

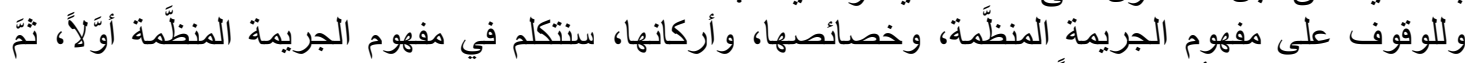
نتناول خصائصها و أركانها ثانياً.

\section{الفصل الأوَّل \\ ماهية الجريمة المنظمَّة عبر الوطنية}

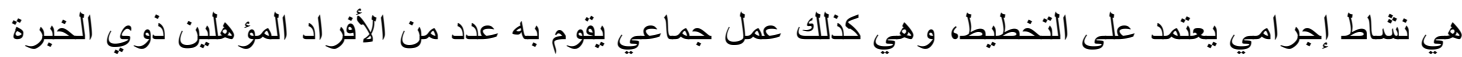

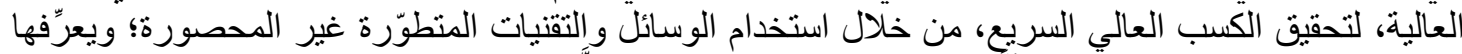

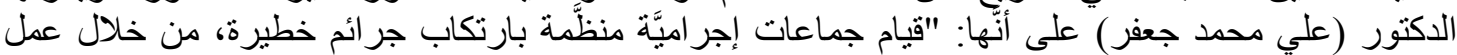

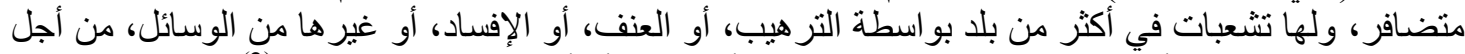

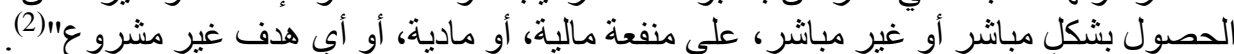

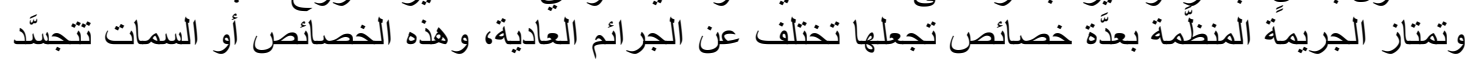
1- التخطيط: يُعتبر العامل الأهم في الجريمة المنظَّمة، فهو يكفل لها النجاح و الاستمر ار، ويتطلَّب أفر اد مؤهلين

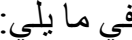
وذوي خبرة عالية.

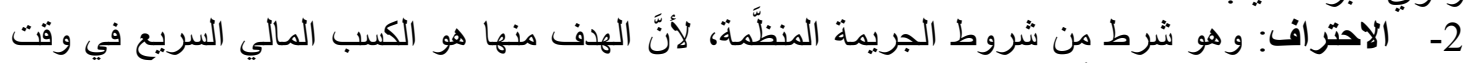

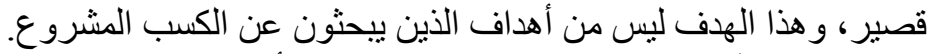

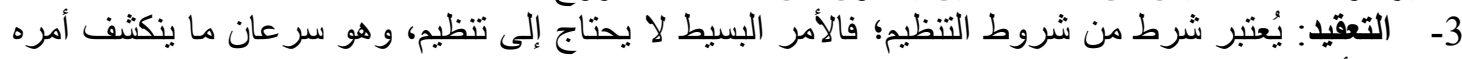

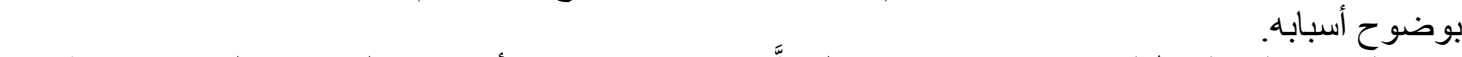
4- القدرة على التوظيف والابتزاز: الإجر ام المنظَّم ذكي في اختيار الأشخاص الذين يتعاملون معهم بطريقة

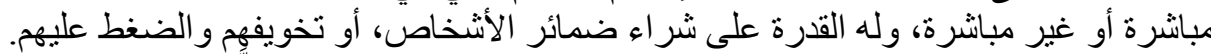

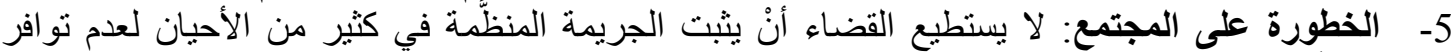

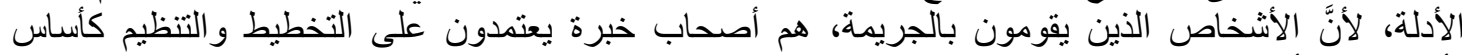

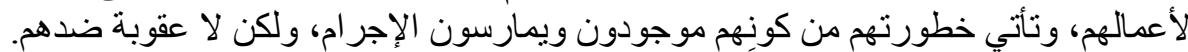

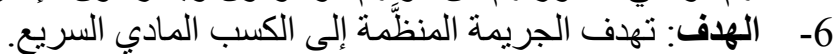

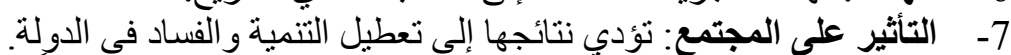

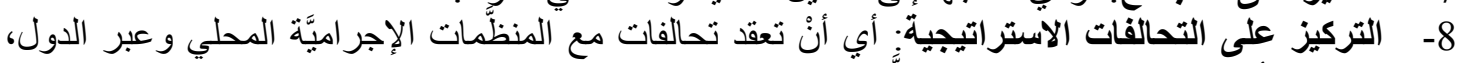

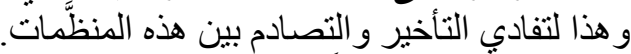

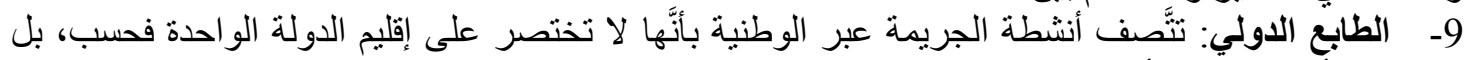

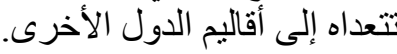

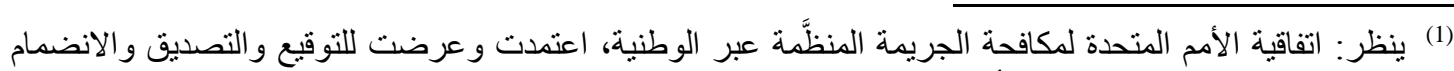

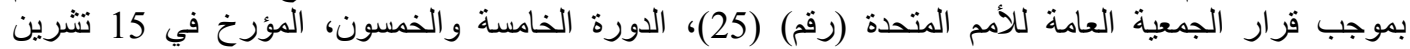

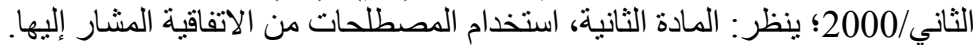
(2) جعفر (الدكتور علي محمد)، داء الجريمة سياسية الوقاية والعلاج، الطبة الطبعة الأولى، (مجد) المؤسسة الجامعية للادراسات و النشر و التوزيع، بيروت، 2003، صلئر داه الجريدة وما بعدها. 


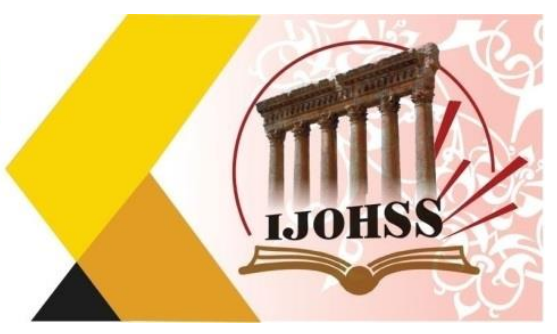

يتعيَّن ضمن مفهوم الجريمة المنظَّمة عبر الوطنية أنْ نتطرَّق إلى المضمون المَرِن و الحصري لهذه الجريمة وفق الآتي:

\section{المبحث الأوَّل

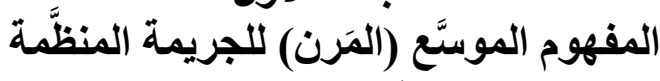

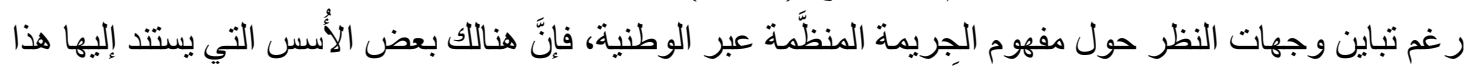

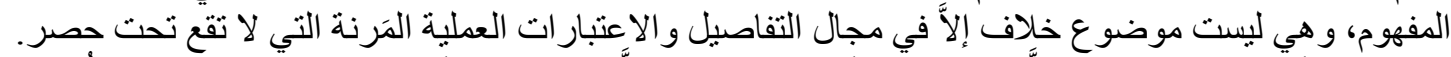

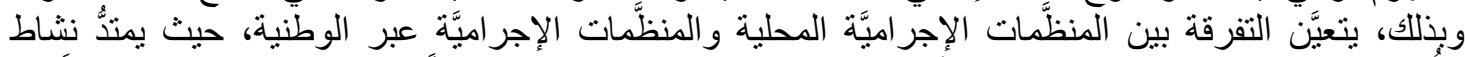

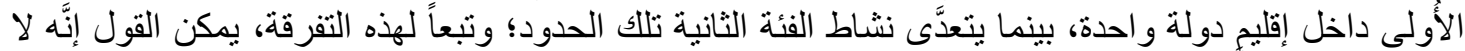

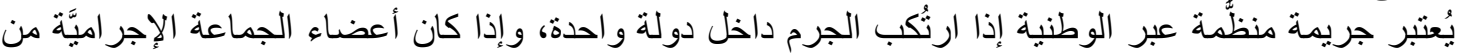

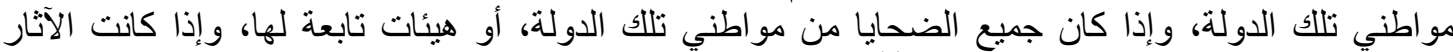

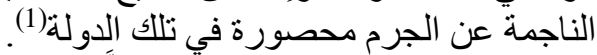

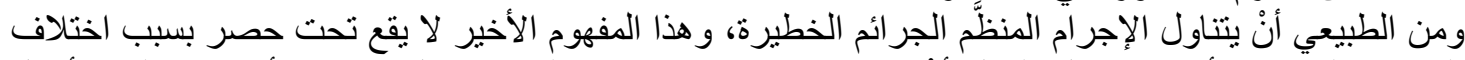

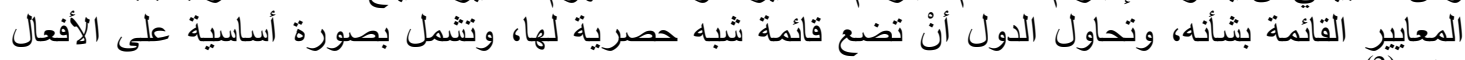
الآتيةة) (2).

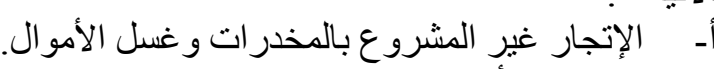

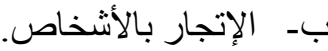

$$
\begin{aligned}
& \text { ج- ت تزيف العملات. } \\
& \text { د- الإتجار غير المشروع بالأشياء الثقافية وسرقتها. } \\
& \text { ه- الإتجار غير المشروع بالمو اد النووية والأسلحة لإساءة استعمالها. }
\end{aligned}
$$

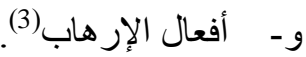

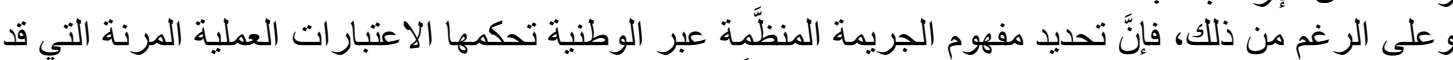

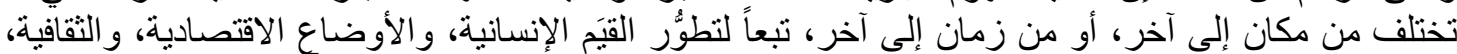

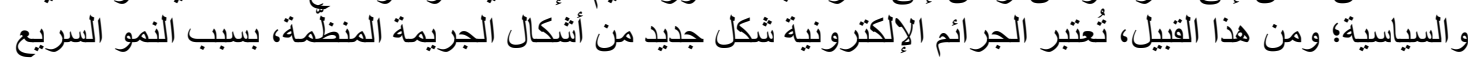

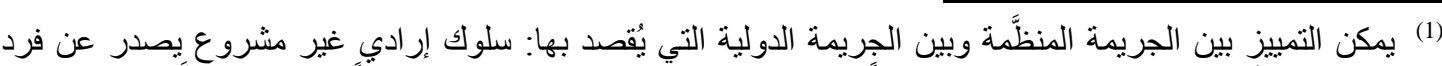

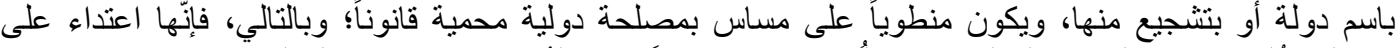

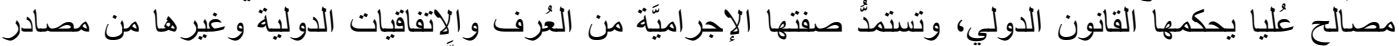

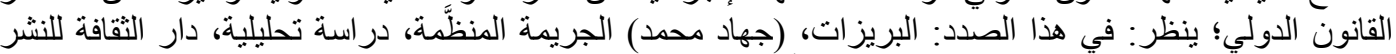

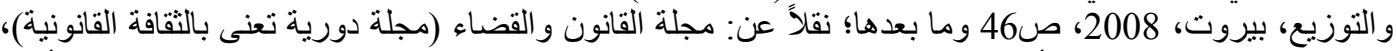
تصدر عن مجلس القضاء الأعلى العراقي، رقم الإيداع في دار الكتب والونائق العر اقية/بغداد/1384، العداء لعدد الأول،

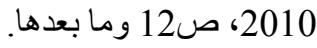
(2) ينظر: المادة ( الثانية ) والملاحظات المتعلقة بها من مشروع اتفاقية الأمم المتحدة لمكافحة الجريمة المنظمَّة عبر

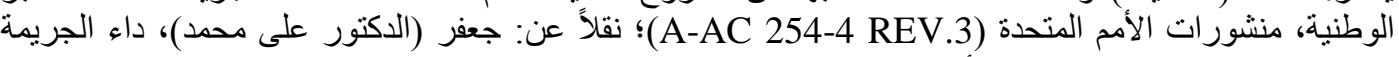

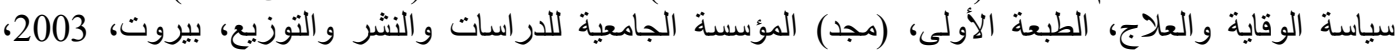
ص28.

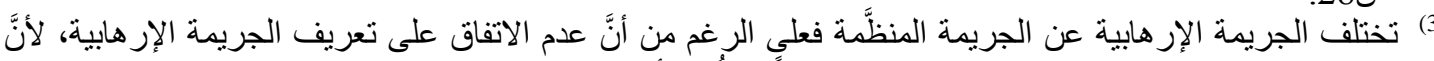

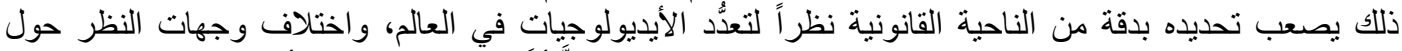

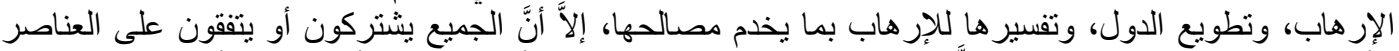

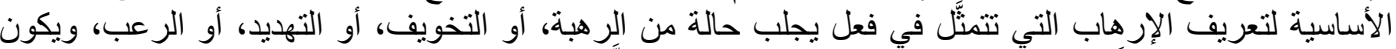
باعثه في الغالب سياسياً سواء ارتكبت من فرد أم من مجمو عة منظمَّة أو من دولة. 


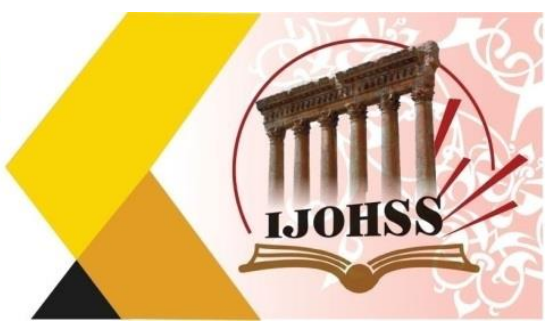

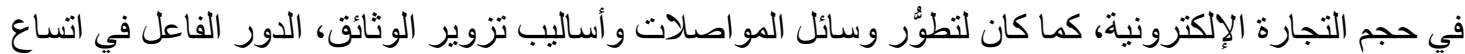

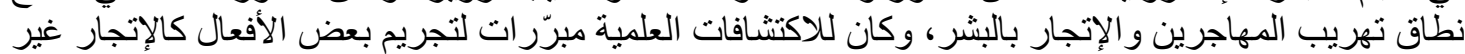

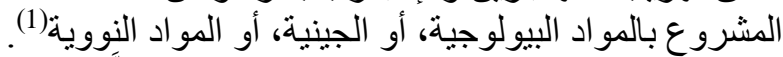

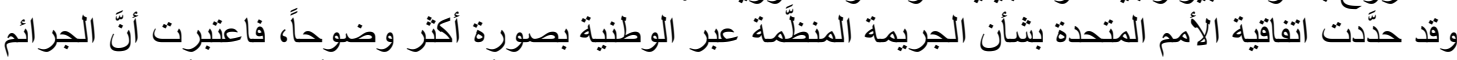

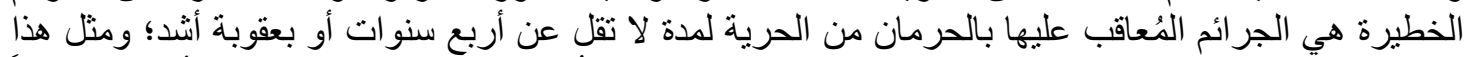

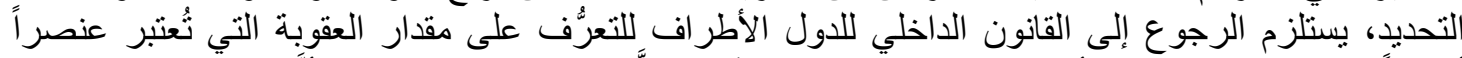

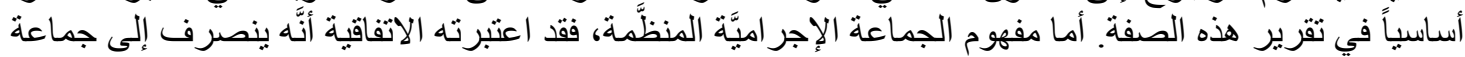

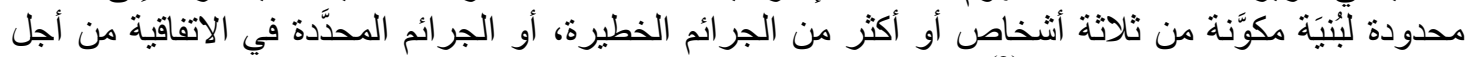
الحصول على منفعة مادية أو مالية (2)

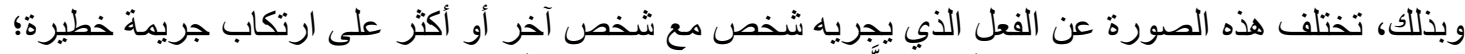

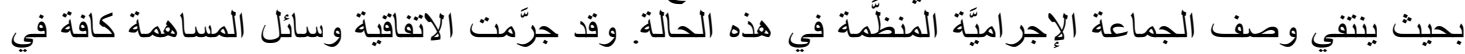

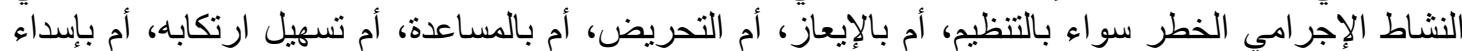

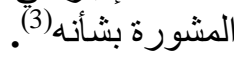

\section{المبحث الثاني \\ المفهوم الحصري للجرائم المنظّمَّة عبر الوطنية}

المضمون السابق والمرن للجريمة المنظَّمة عبر الوطنية شمل إضافة إلى الاتفاقية (اتفاقية الأمم المتحدة بشأنسان

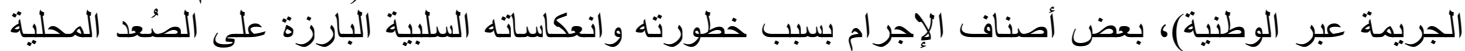

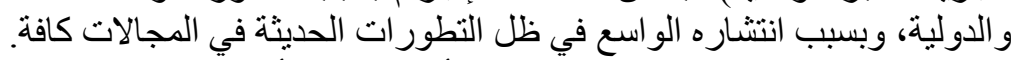

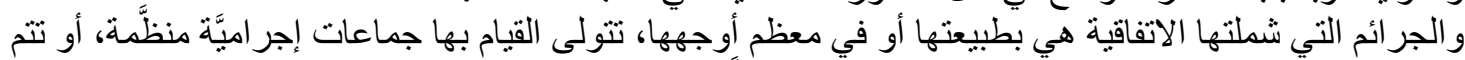

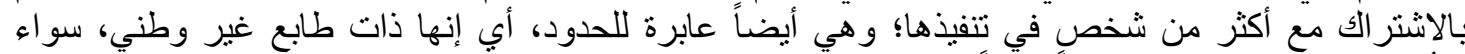

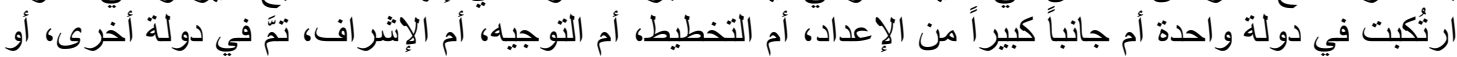

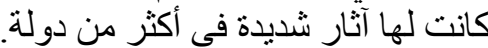

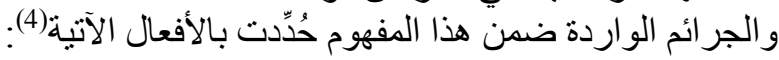

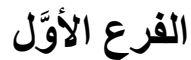

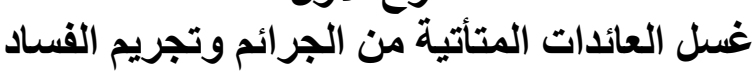

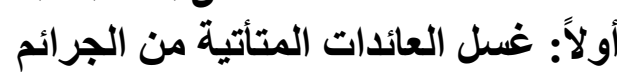

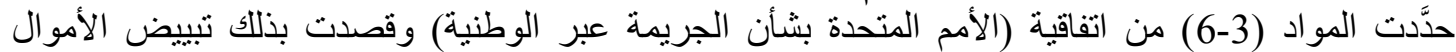

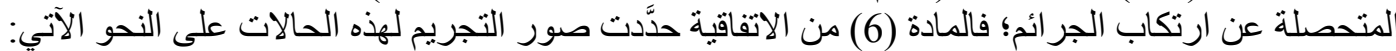

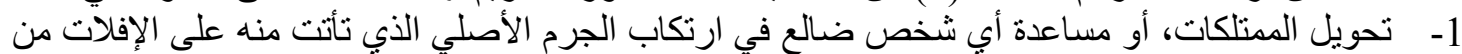
المسؤولية القانونية.

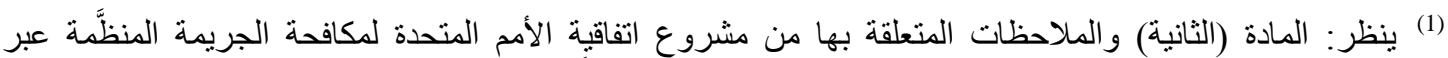

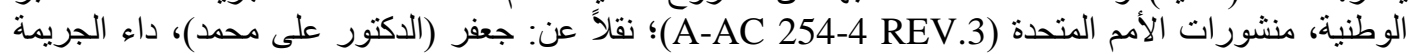

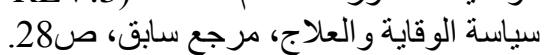

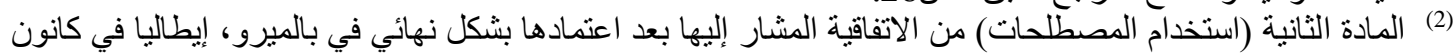

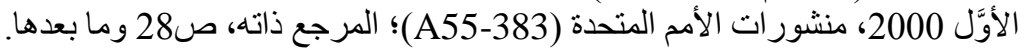

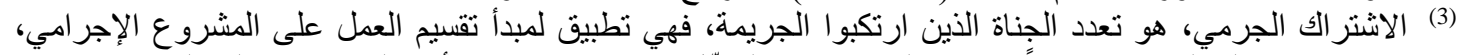

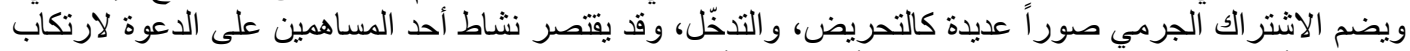

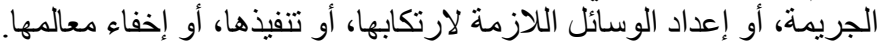

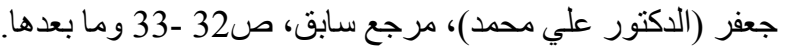




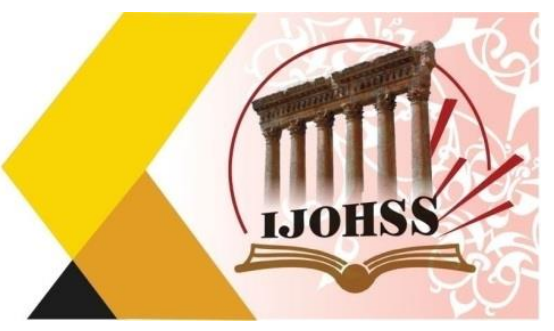

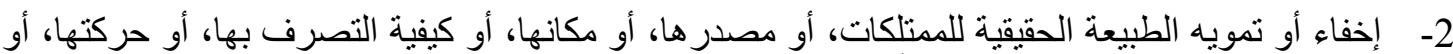

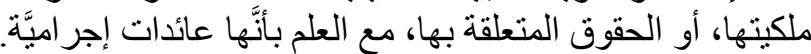

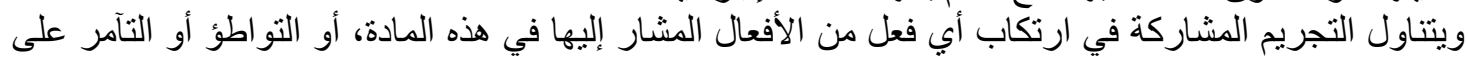

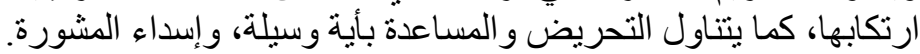

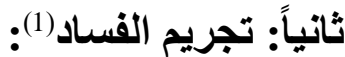

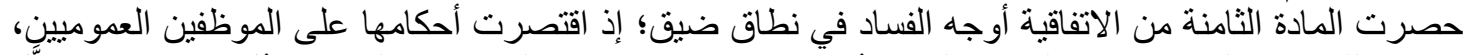

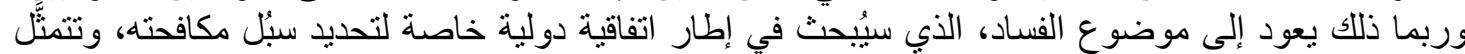

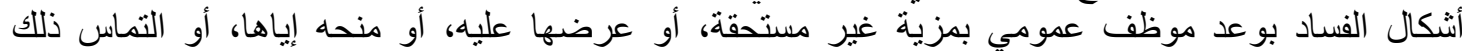

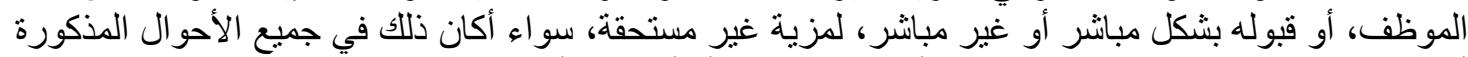

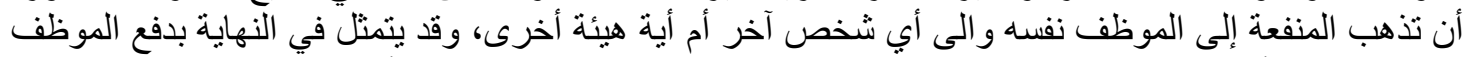

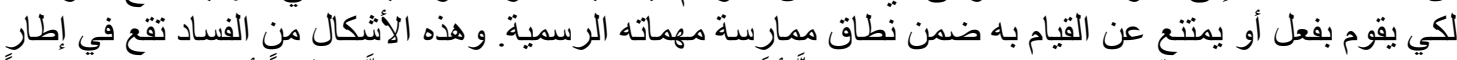

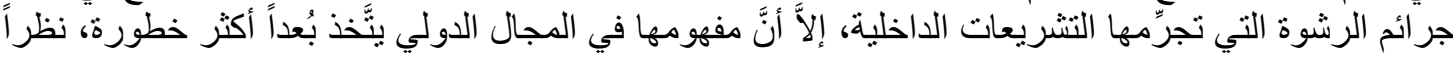
للصفقات الكبيرة غير المشروعة تهنة التي تنتج عنها. الفرع الثاني تجريم إعاقة سير العدالة والآتجار بالأشخاص

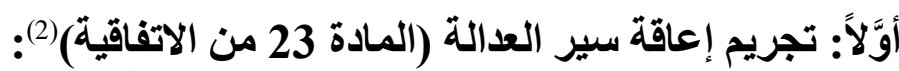

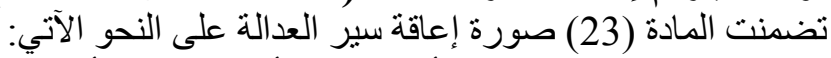

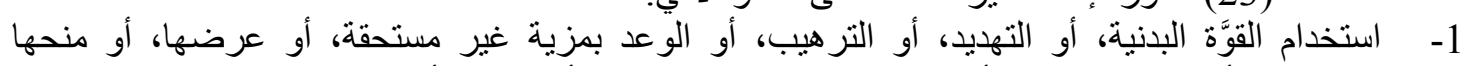

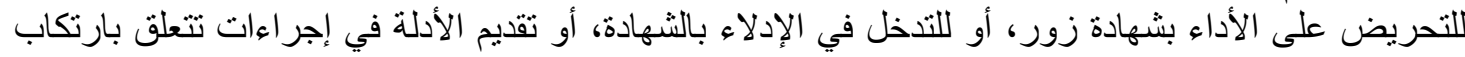
جر ائم مشمولة بهذه الاتفاقية.

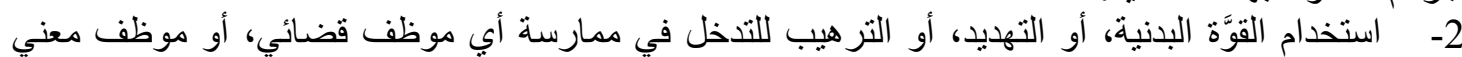

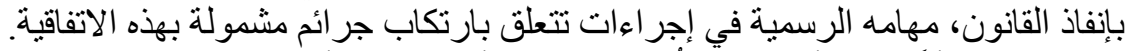

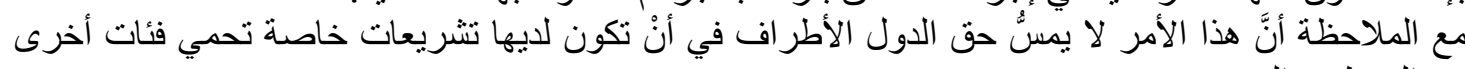
من الموظفين العموميين.

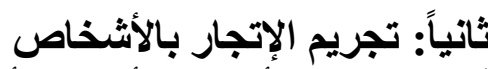

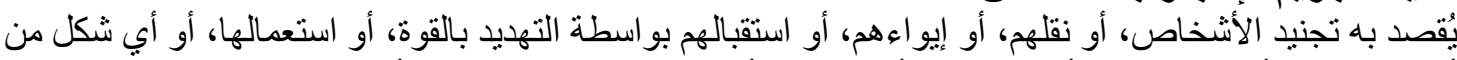

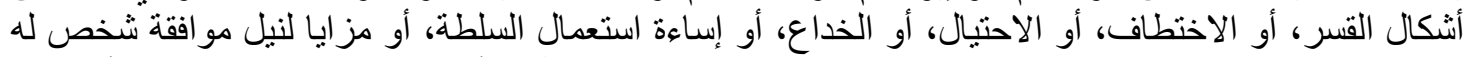

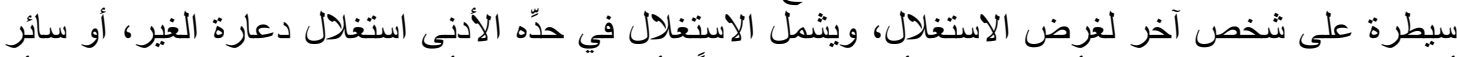

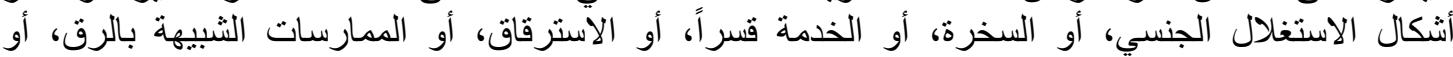

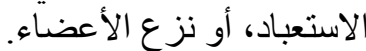
ونطاق التجريم يشمل الثرو الإن الثراء في ارتكاب هذه الجر ائم، أو المشاركة بارتكابها بأية صورة كانت، و الأغر اض من الاتفاقية تتحدّد أساساً بالمسائل الآتية:

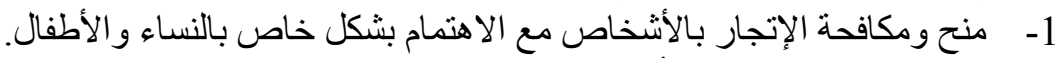

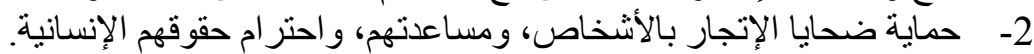

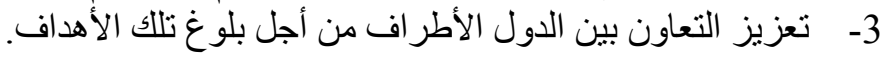

(1) جعفر (الاكتور علي محمد)، مرجع سابق، ص32 (33 -33 وما بعدها.

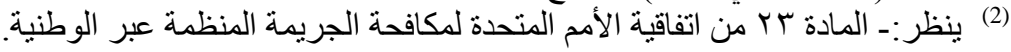




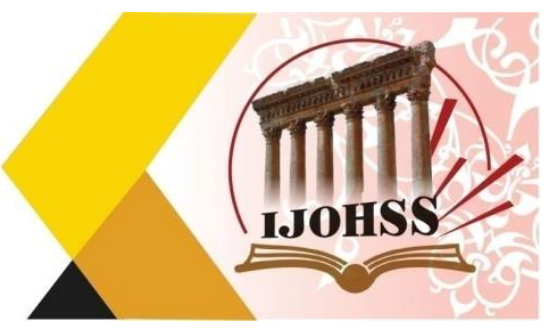

\section{أركان الجريمة المنظظَّمة}

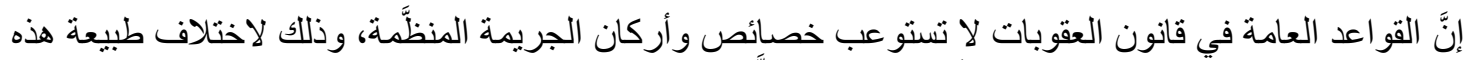

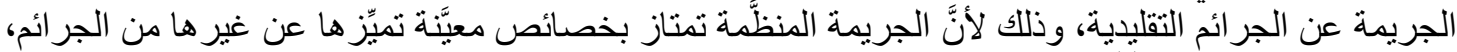

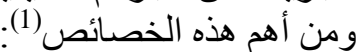

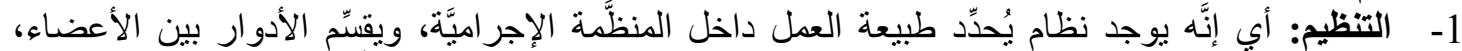

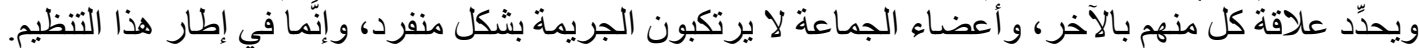

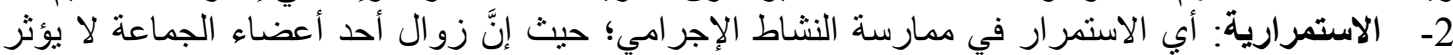

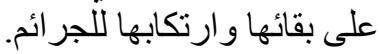

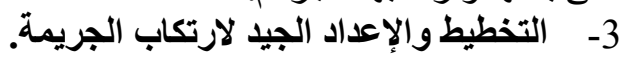

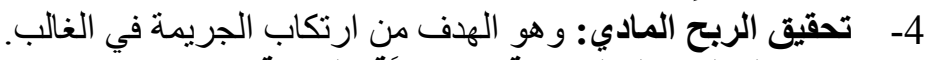

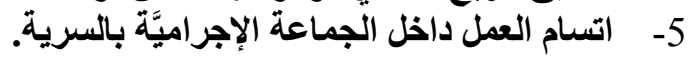

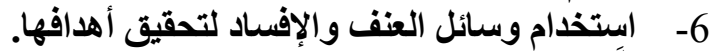

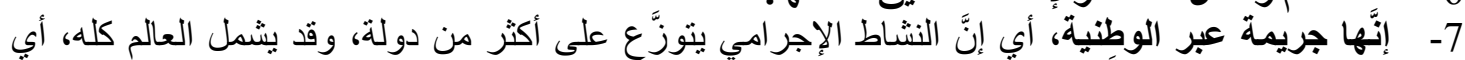

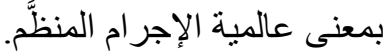

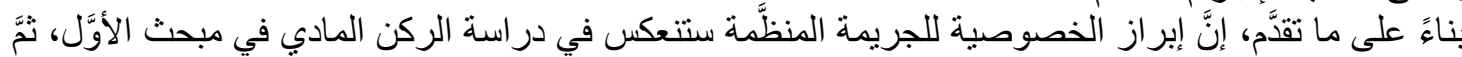

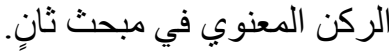

\section{المبحث الأوَّل \\ الركن المادي للجريمة المنظَّمة}

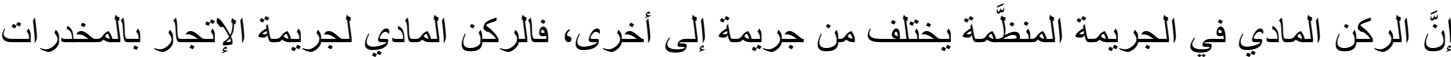

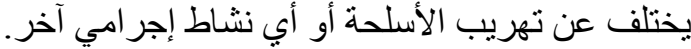

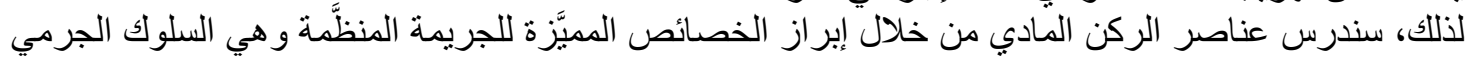
و النتيجة وسنبينهما في الفرعين الآتيين:

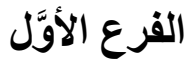

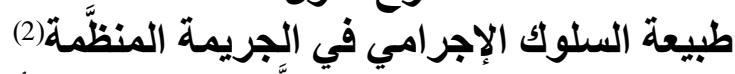

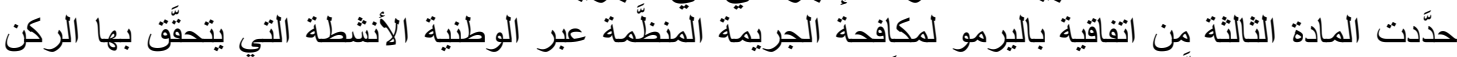

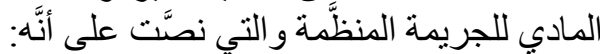
"يتعينٌ على كل دولة طرفة أُّنْ تعتمد ما قد بلزم من تدابير تشريعية وتدابير أخرى لتجريم الأفعال التالية جنائباً، عندما تُرتكب عمداً: أولاً: أبي من الفعلين التاليين أو كليهما، باعتبار هما جريمتين جنائيتين متميزتين عن الجرائم التي تتطوي على التئ

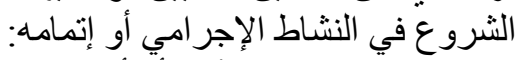

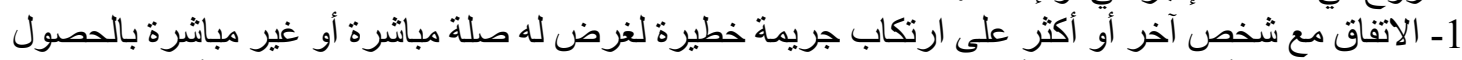

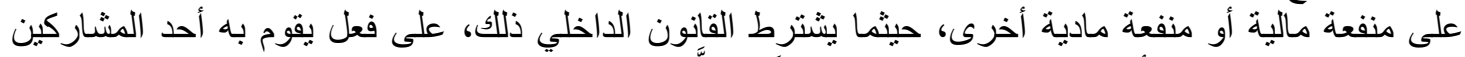

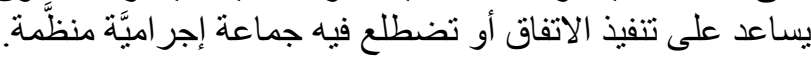

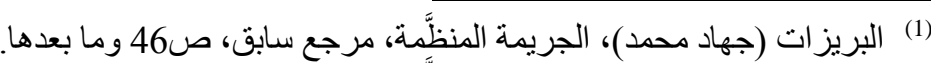

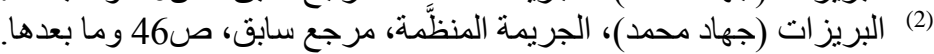


International Journal on Humanities and Social Sciences

website:www.ijohss.com

Email:editor@ijohss.com

العداد(22) يوليو 2021

ISSN: 2415 - 4822

Volume (22) July 2021

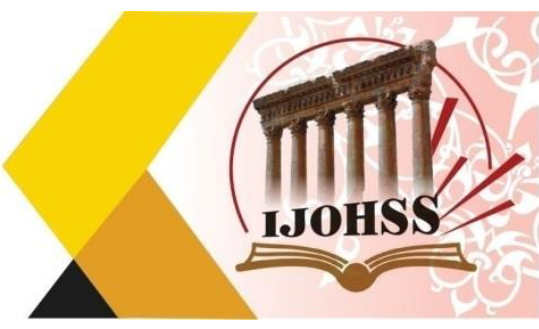

2- قيام الثخص، عن علم بهذف جماعة إجراميَّة منظّمة ونشاطها الإجرامي العام، أو بعزمها على ارتكاب

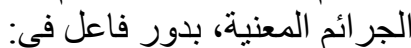
أ. الأنشطة الإجر اميَّة للجماعة الإجر اميَّة المنظَّمة.

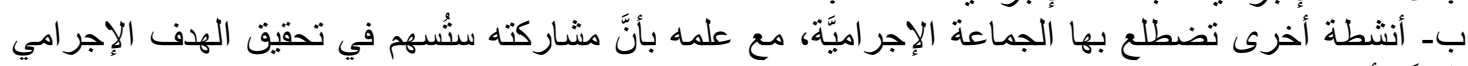

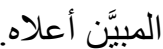

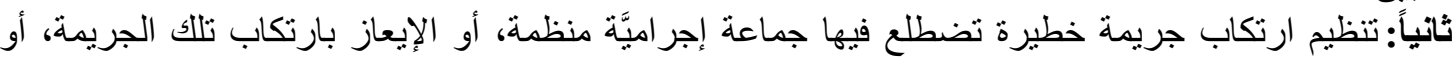

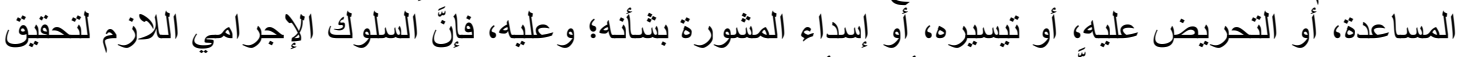

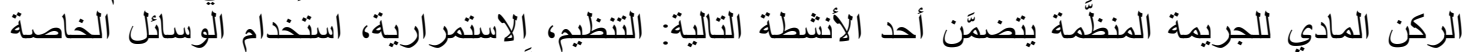

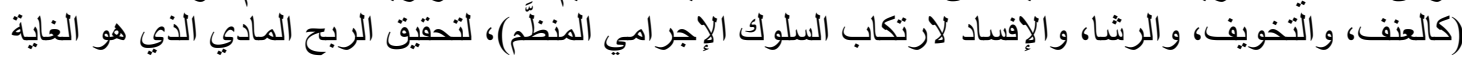

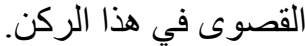

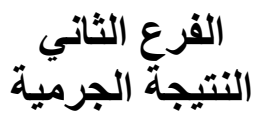

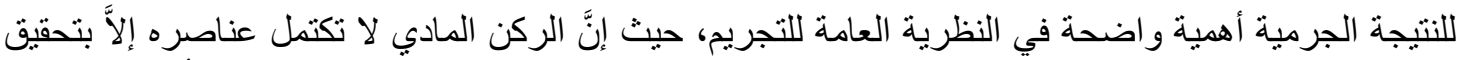

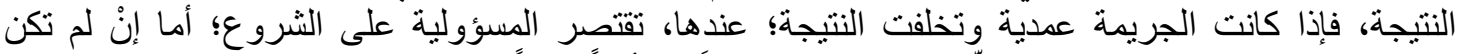

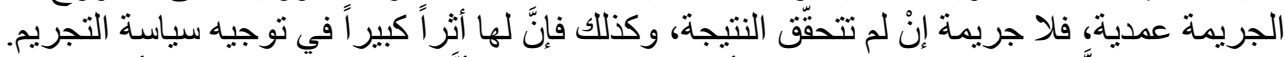

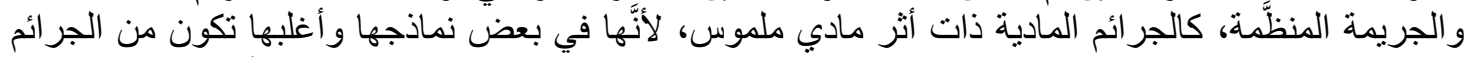

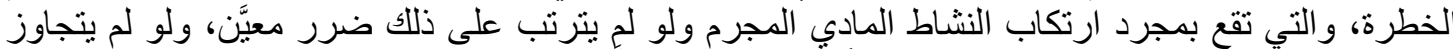

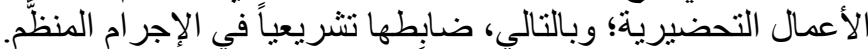

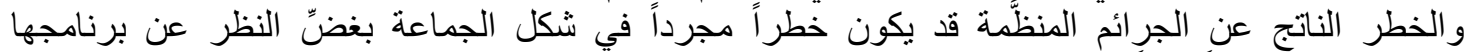

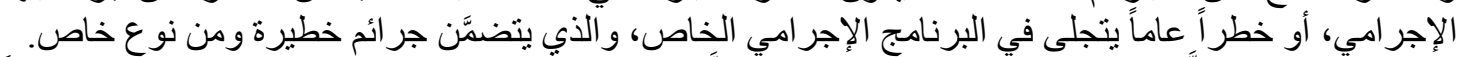

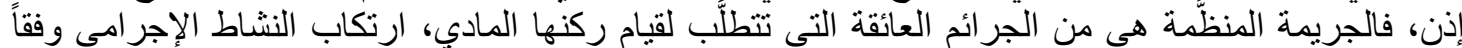

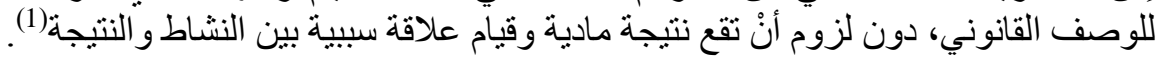

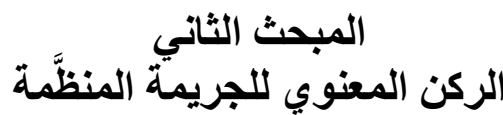

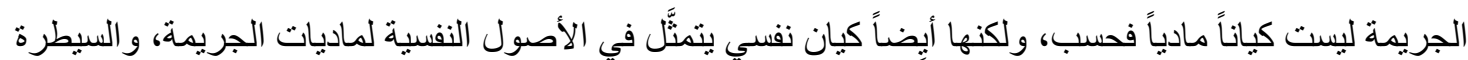

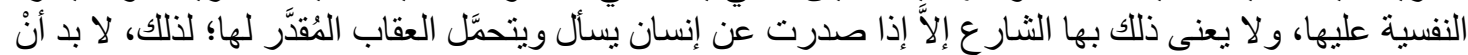

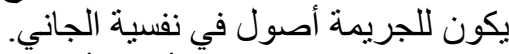

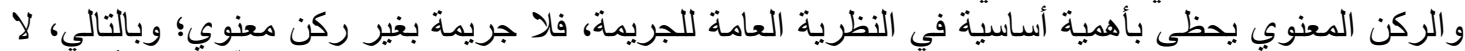

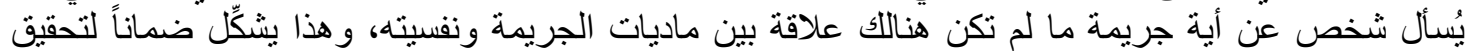

العدالة) (2) (2) من هنا، فإنَّ الثخص عندما يرتكب نشاطاً إجر امياً، لا يُعدُّ مُرتكباً للجريمة إلاًّ إذا كان جهازه العقلي و النفسي في

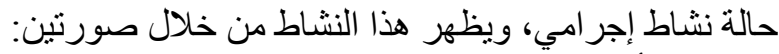
الصورة الأولى: اتجاه إر ادة الجاني إلى عناصر الجريمة، وهي الجئ الفعل و النتيجة، وهو ما يُسمى بالقصد الجنائي.

$$
\text { (1) البريز ات (جهاد محمد)، مرجع سابق، ص } 46 \text { و وما بعدها. }
$$

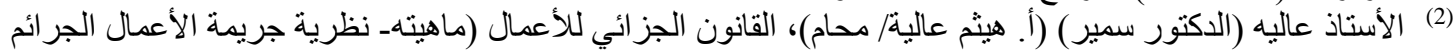

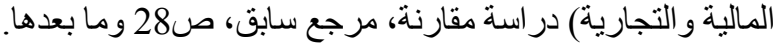




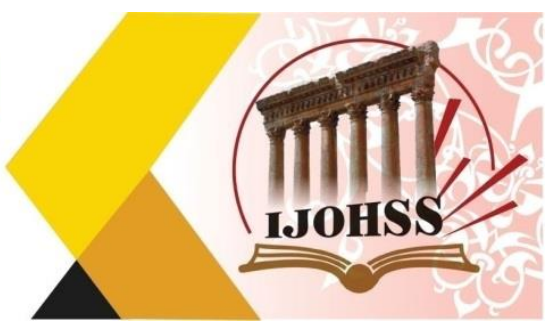

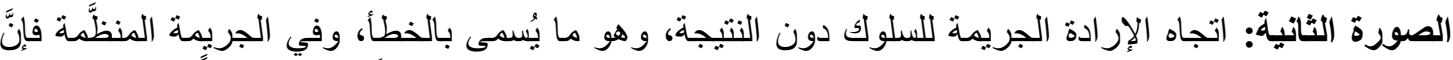

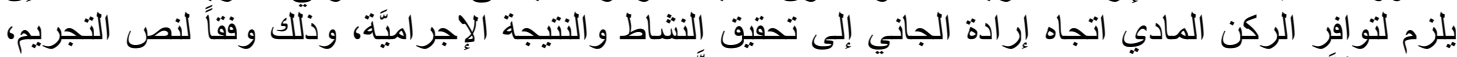

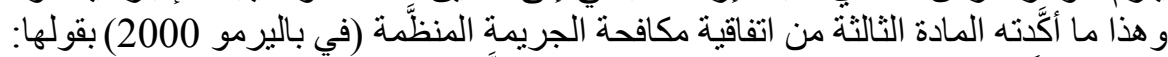

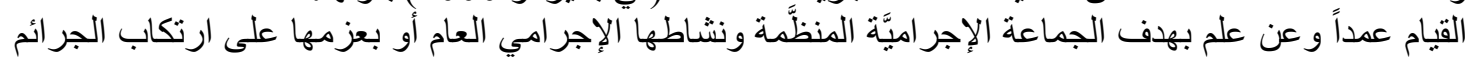
المعينة.

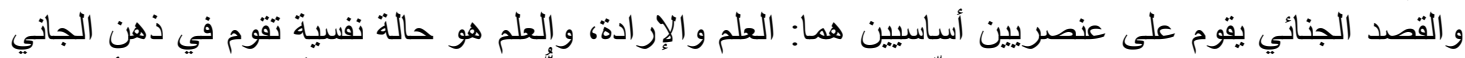

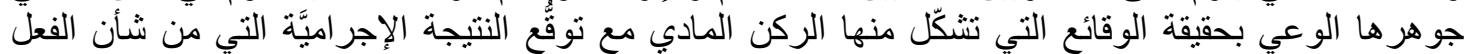

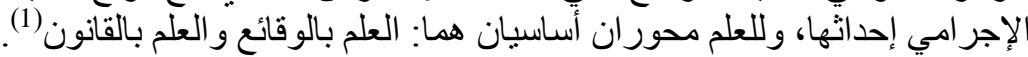

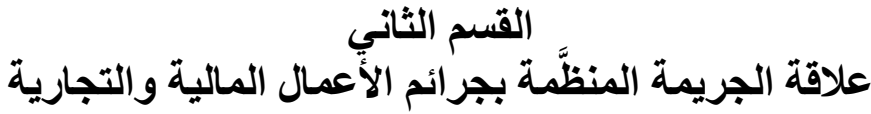

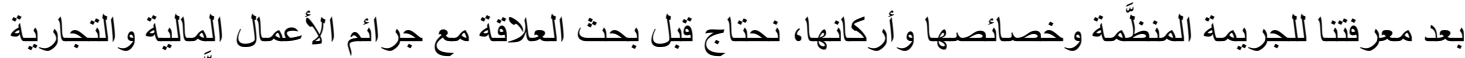

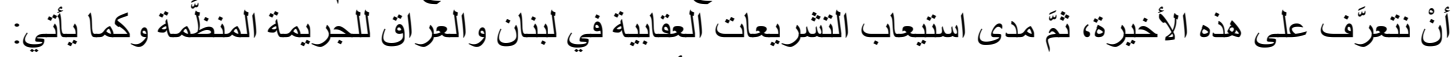
الفصل الأوَّل

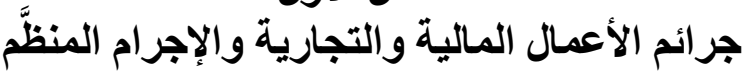

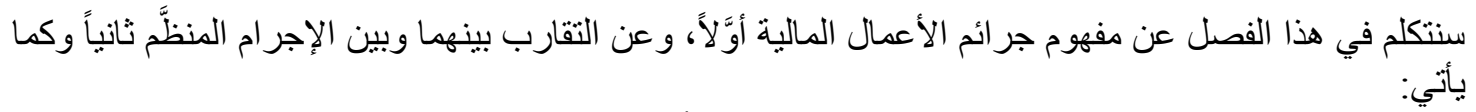

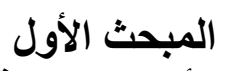

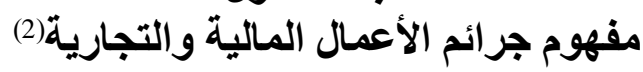

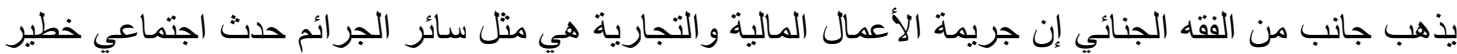

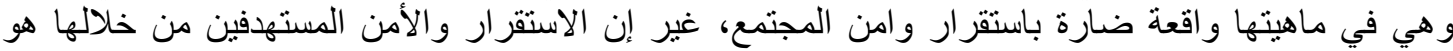

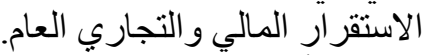

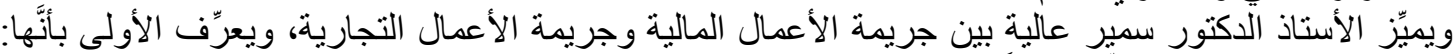

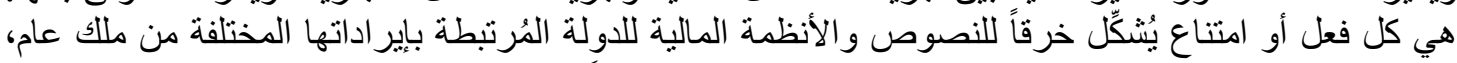

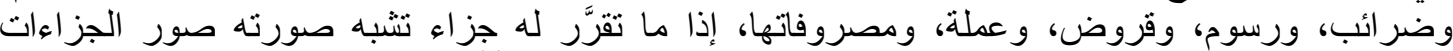

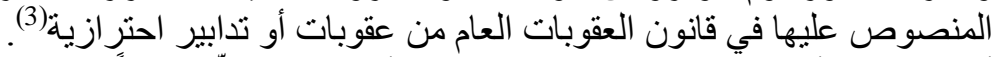

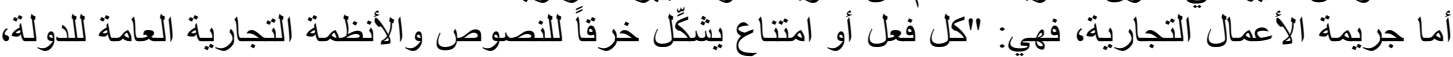

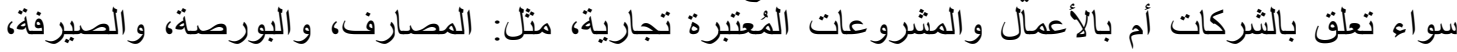

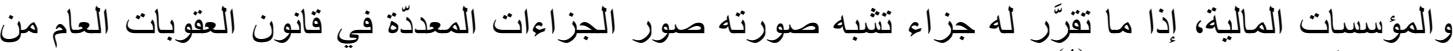

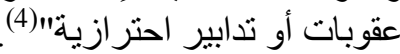

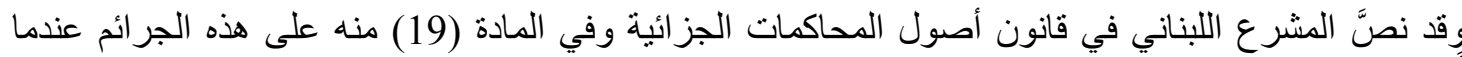

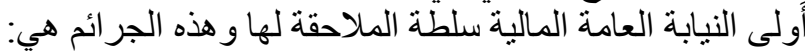

$$
\text { (1) البريز ات (جهاد محمد)، مرجع سابق، ص صكت } 46 \text { وما بعدها. }
$$

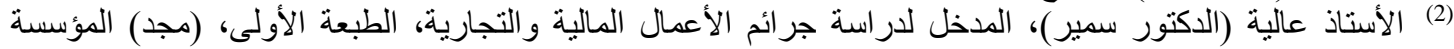

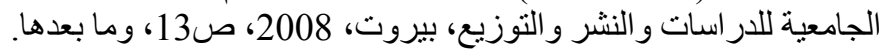

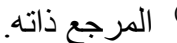
(4) الأستاذ عاليه (الدكتور سمير)، المدخل لار اسة جر ائم الأعمال المادية و التجارية، مرجع سابق، ص13، وما بعدها. 


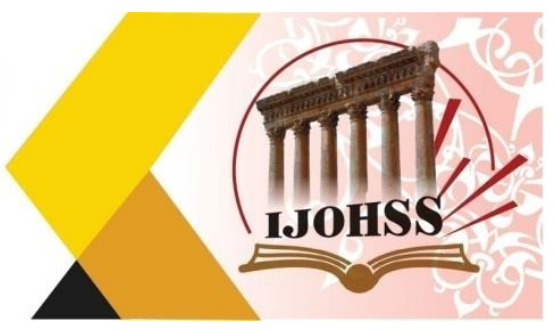

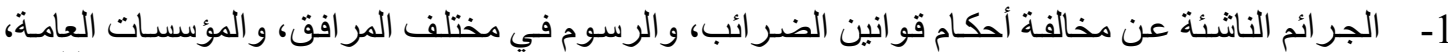

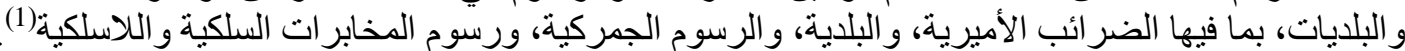

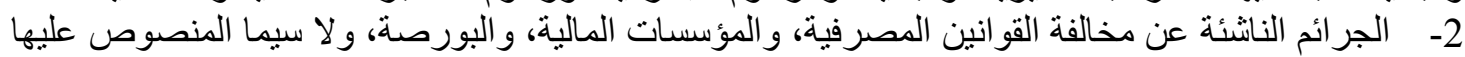
في قانون النقد و التسليف.

3- الجر ائم النانئة عن مخالفة قوانين الثركات المساهمة وجر ائم الثركات المتعددة الجنسية.

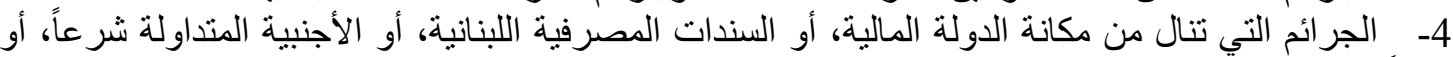

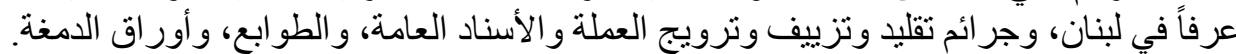

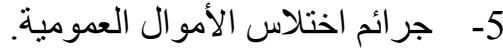

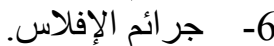

ويذكر الأستاذ الدكتور عالية أنَّ جرائم الأعمال المالية والتجارية من حيث الطبيعة ليست من الجرائم التقليدية

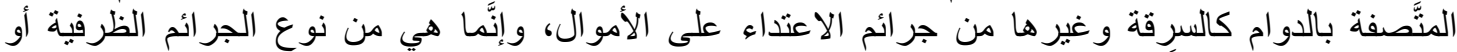

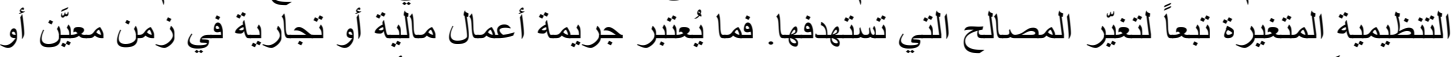

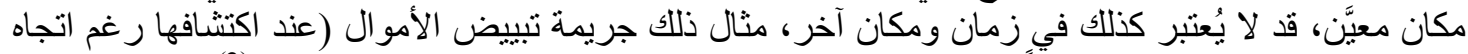

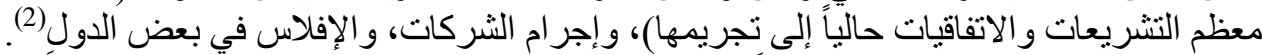

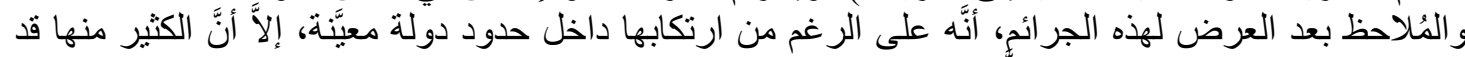
تكون له علاقة وثيقة بالجريمة المنظمة عبر الوطنية كما سنلاحظ ذلك.

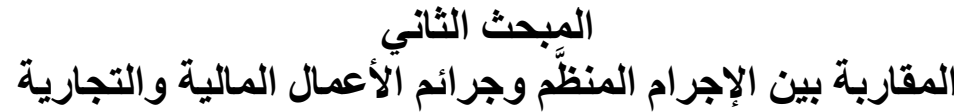

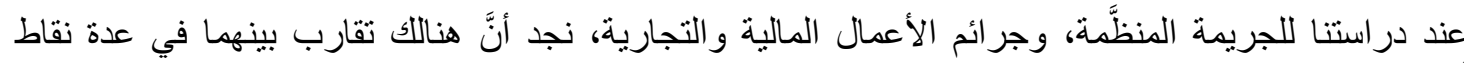

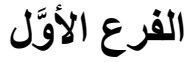 \\ من حيث السلوك الإجرامي ووسائل ارتكاب هذا السلوك}

أبرز ها:

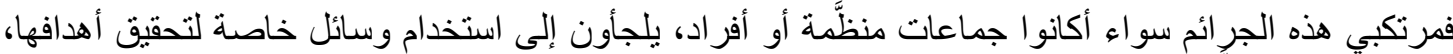

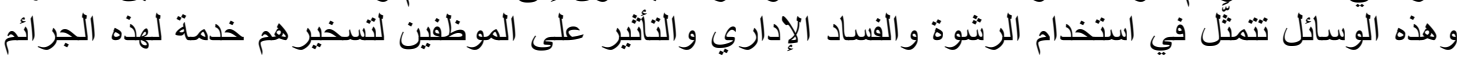

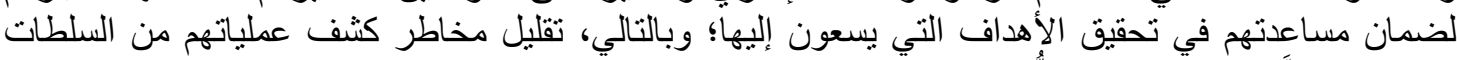

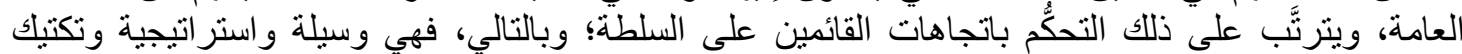
لإكمال الأهداف الإجر اميَّة.

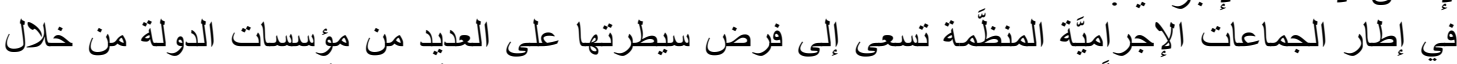

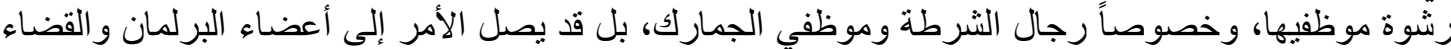

نظر أ لأهمية موققهم السياسي و الاجتماعي. وتمارس هذه الجماعات ذللك لتحقيق هدفين:

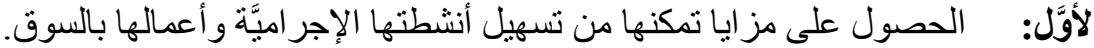

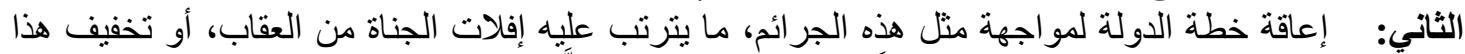

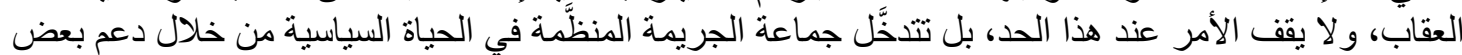

الحملات الانتخابية بتوفير التمويل اللازم لها، ليوفر مز ايا وتسهيلات تهم هذه الجماعات مستقبلاً. 


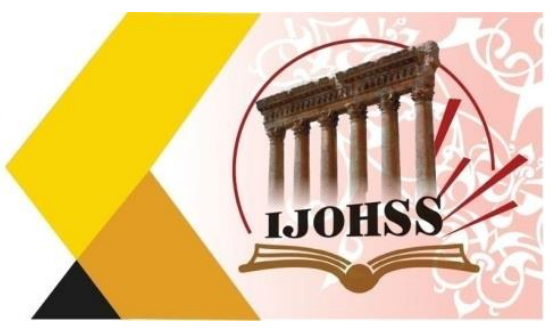

كما وتعتبر جريمة اختلاس الأمو ال من أهم الجرائم المرتبطة بالفساد الإداري، فضلاً عن ارتباطها بعملية غسيل

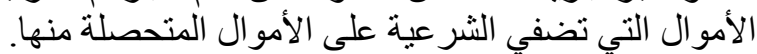

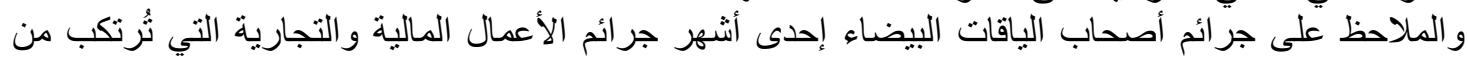

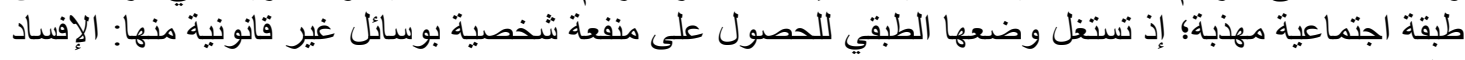

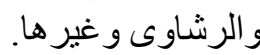

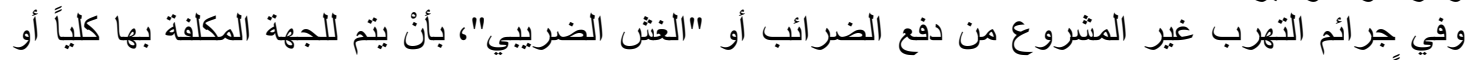

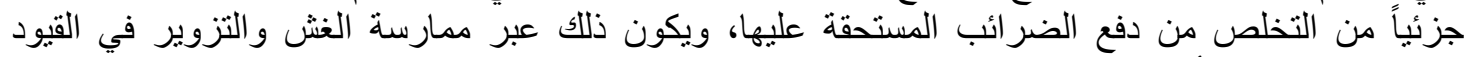
المخالفة للقو انين و الأنظمة الضريبية المعتمدة.

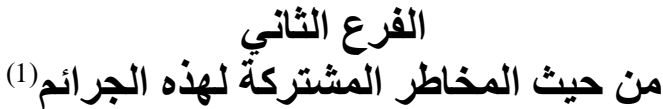

يكون في الغالب الهدف من ارتكاب الجرائم المنظَّمة هو تحقيق الربح المادي وخصوصاً الأرباح الطائلة

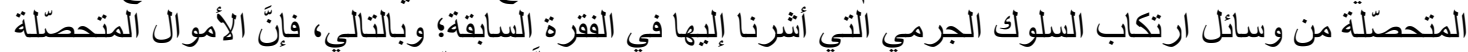

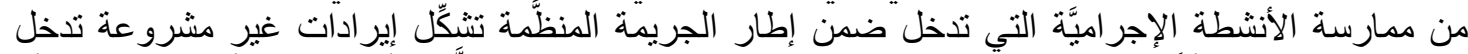

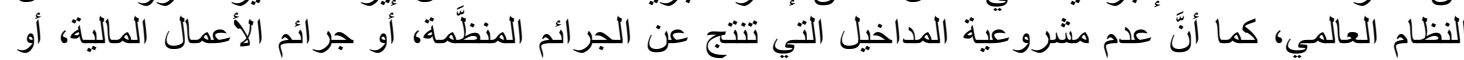

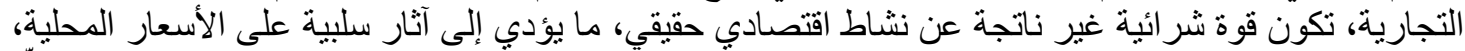

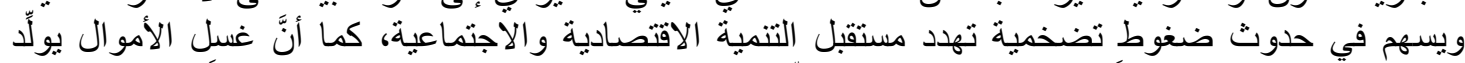

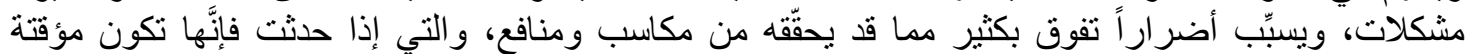

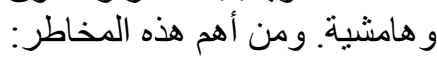

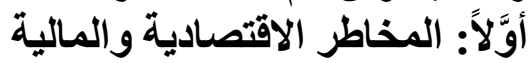

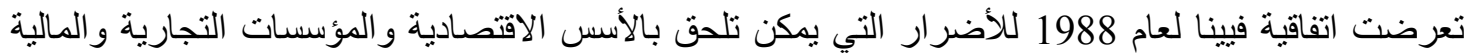

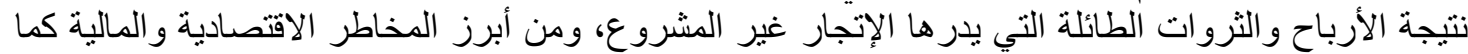

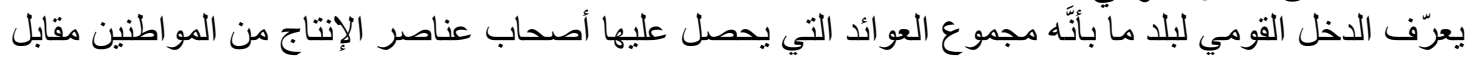

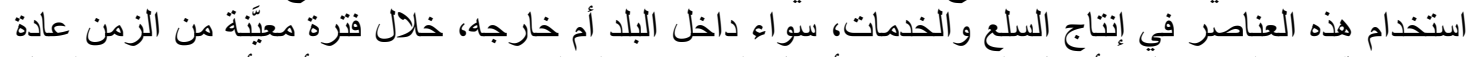

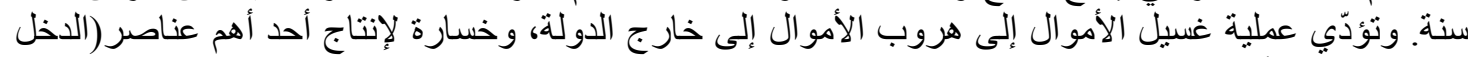

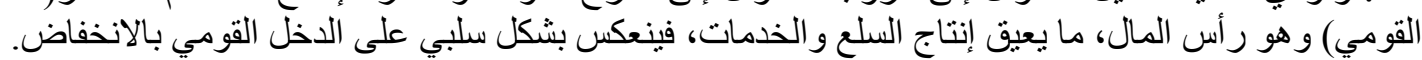

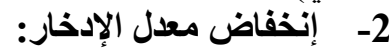

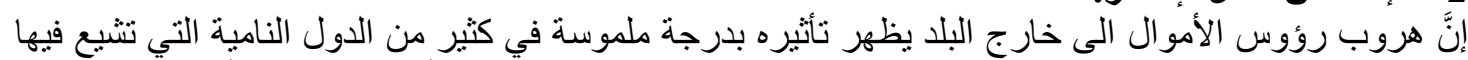

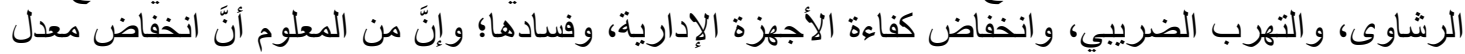

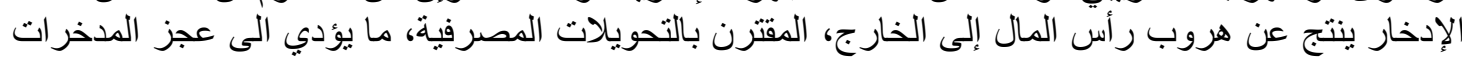
المحلية عن الوفاء باحتياجات الاستثمار.

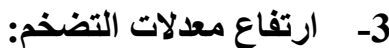

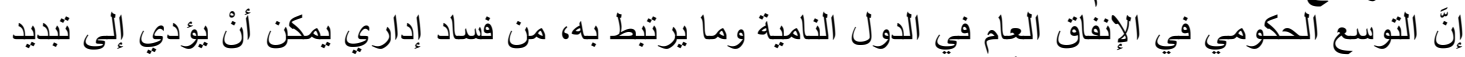

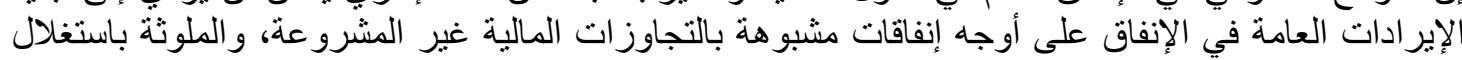

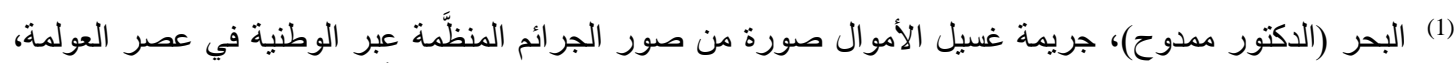

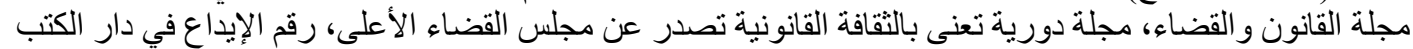

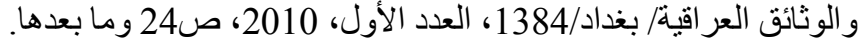


International Journal on Humanities and Social Sciences

website:www.ijohss.com

Email:editor@ijohss.com

العدد(22) يوليو 2021

ISSN: $2415-4822$

Volume (22) July 2021

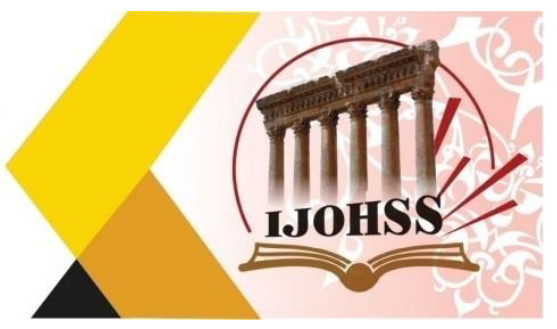

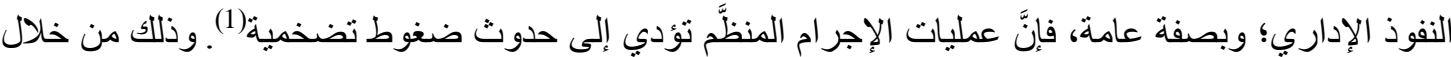

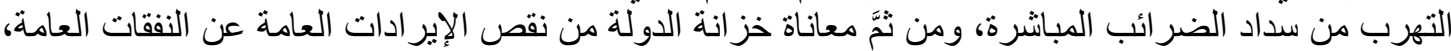

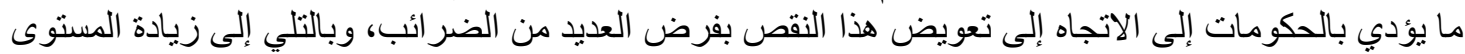

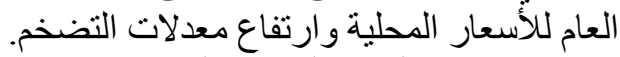

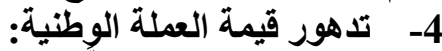

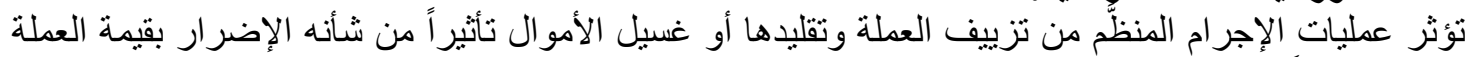

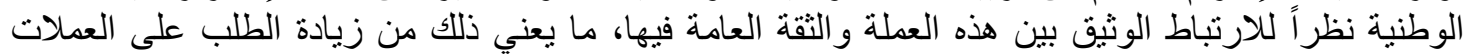

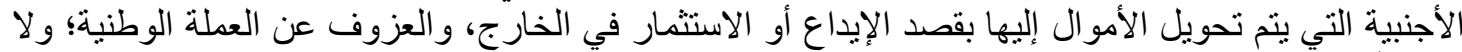

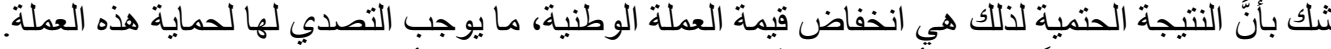

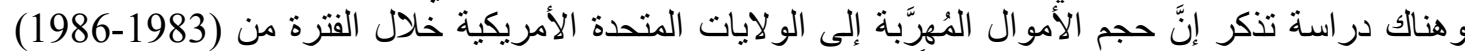

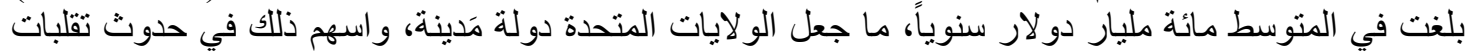

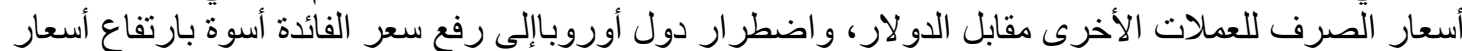

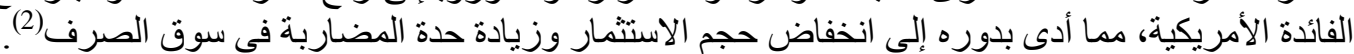

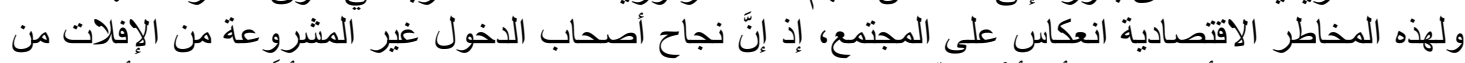

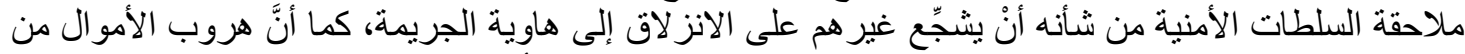

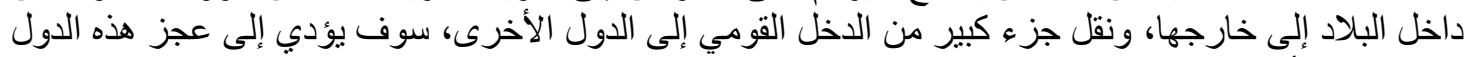

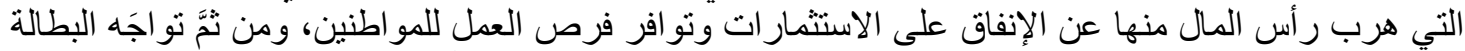

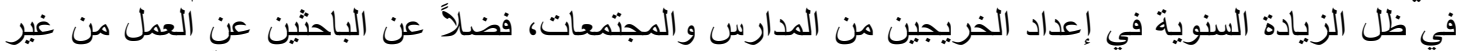

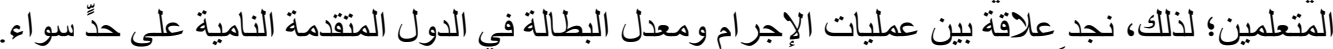

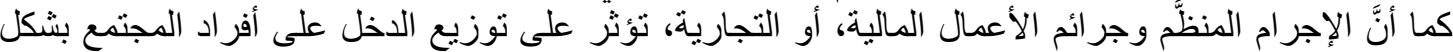

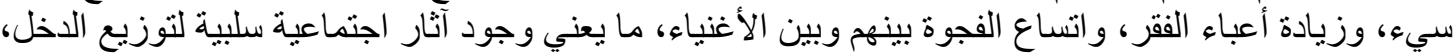

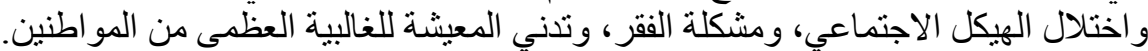

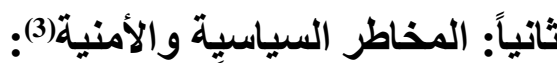

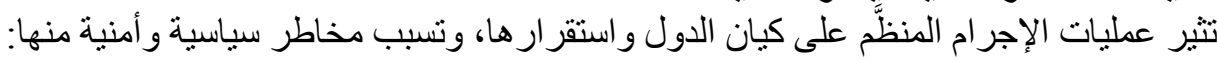

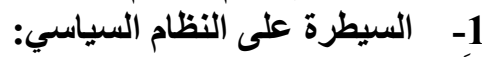

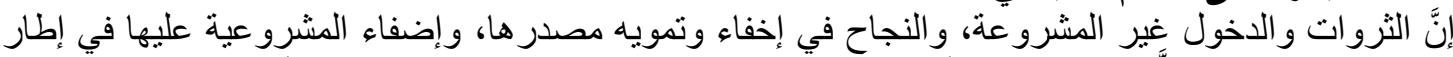

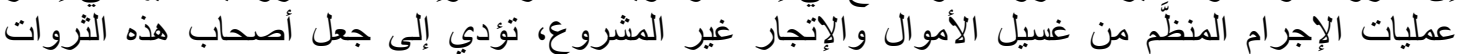

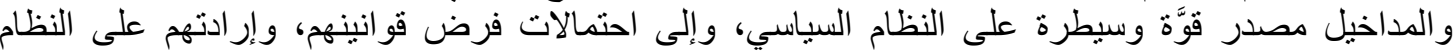

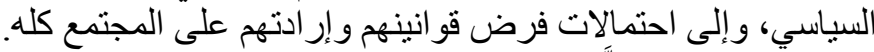

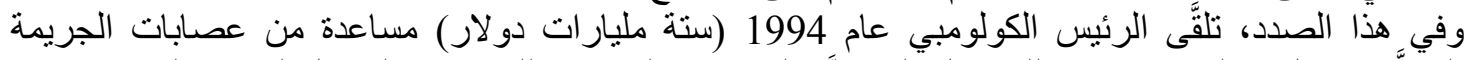

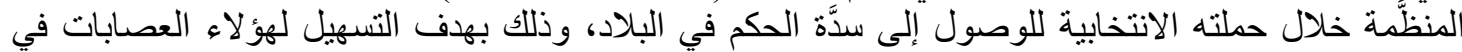

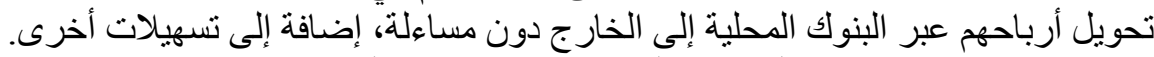

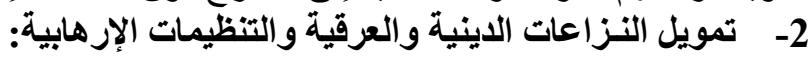

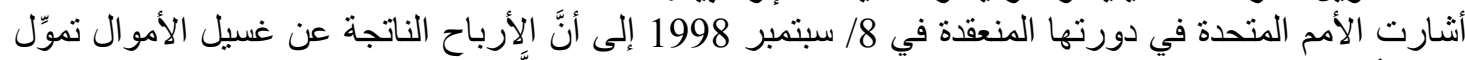

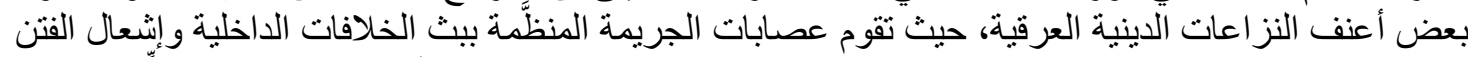

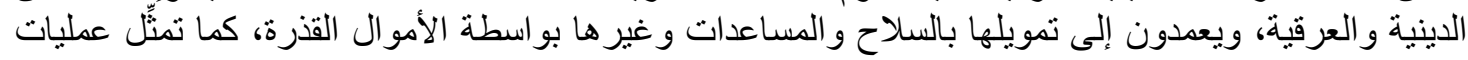

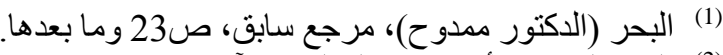

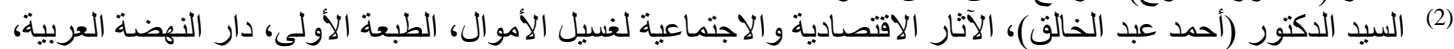

البحر (الدكتور ممدوح)، مرجع سابق، ص23 صو 23 وما بعدها. 


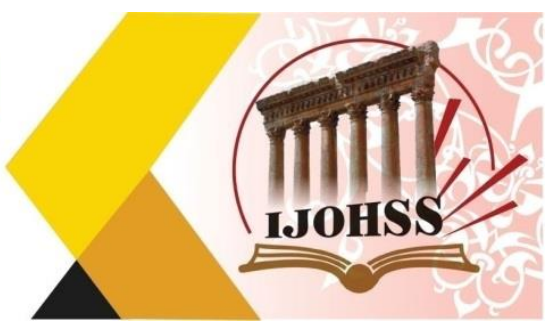

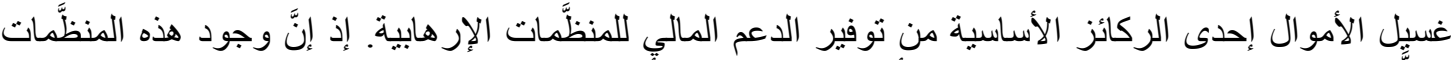

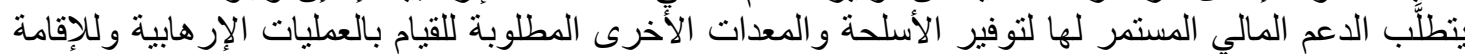
و الإعاثة.

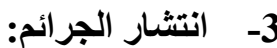

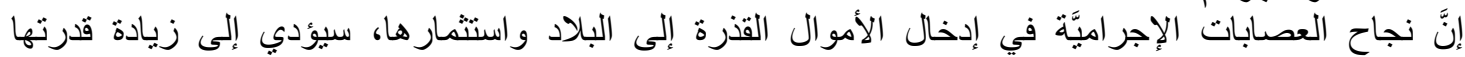

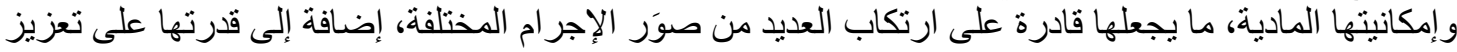

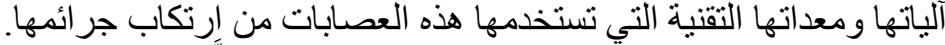

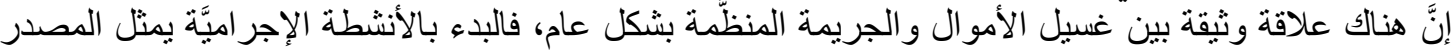

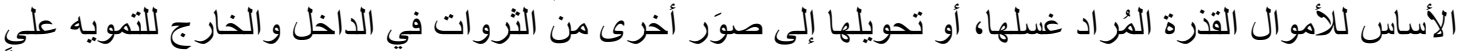

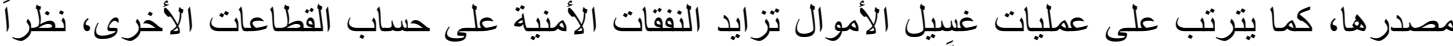

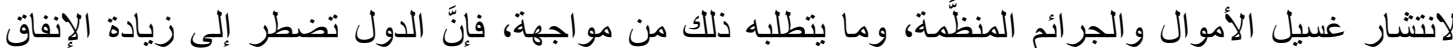

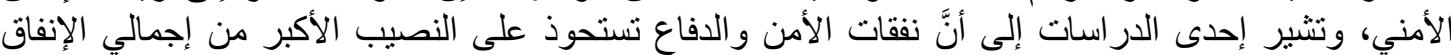

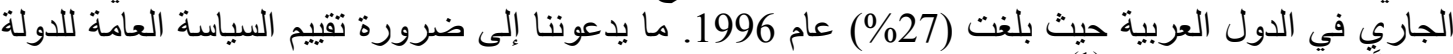

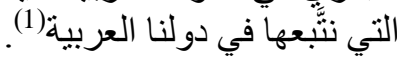

$$
\begin{aligned}
& \text { مدى استيعاب التشريع العقابي اللبناني والعراقي اقي للإجرام المنظًّّ }
\end{aligned}
$$

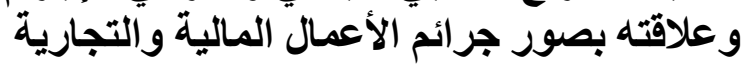

$$
\begin{aligned}
& \text { يقتضي الكلام حول استيعاب التشريعات في لبنان و العر اق أنْ نقسِّم الفصل كما يأتي: } \\
& \text { المبحث الأول } \\
& \text { في التثريع العقابي اللبناني }
\end{aligned}
$$

تناغم التشريع العقابي مع السياسة الدولية سواء على صعيد مكافحة المخدرات و المؤثرات العقلية أم الإتجار غير

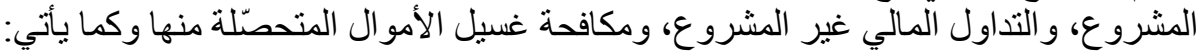

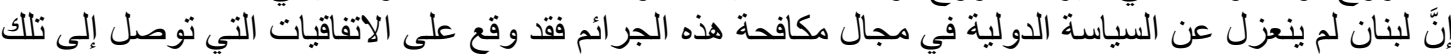

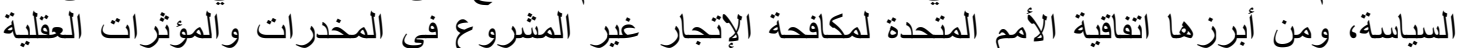

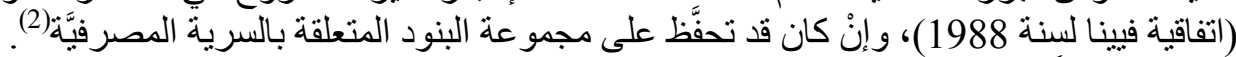

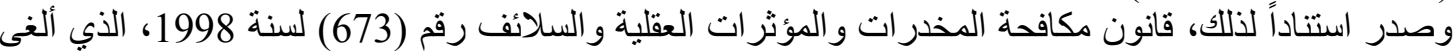

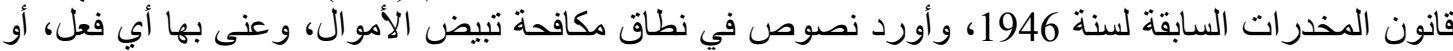

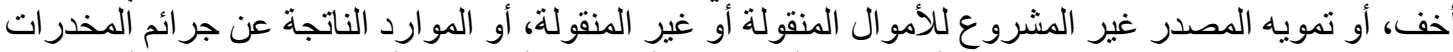

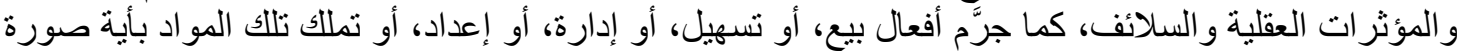

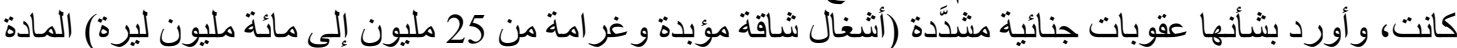

وصدر القانون رقم (253) لسنة 2000، بشأن شن نظام الشركات المحصور نشاطها خارج لبنان (الأوف شور )،

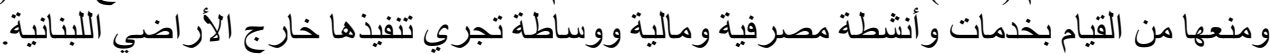

(1) غسيل الأموال في العالم وتداعياته السلبية، مركز الخليج للاراسات الاستر اتيجية الموسوعة الأمنية العربية، الطبعة

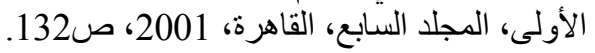

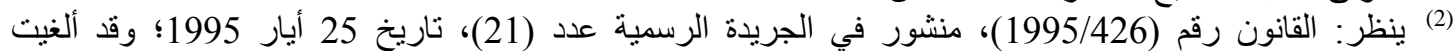
التحفظات الواردة بشأن السرية المصرفية بموجب المادة (15) من قانون مكافحة تبييض الأمو ال رقم (318) الصادر في 2001/4/20. 


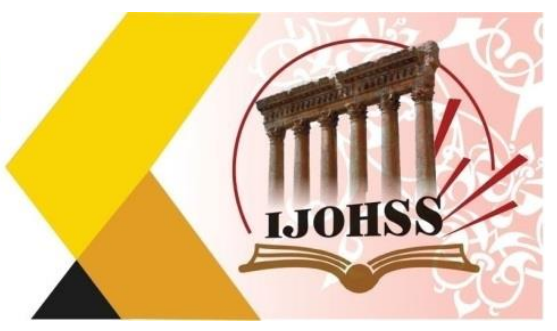

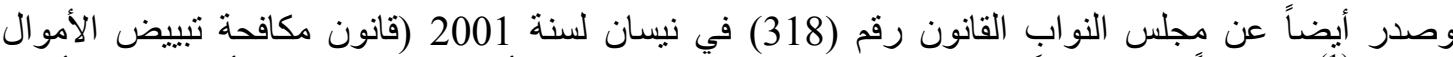

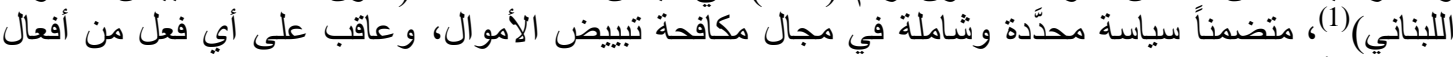

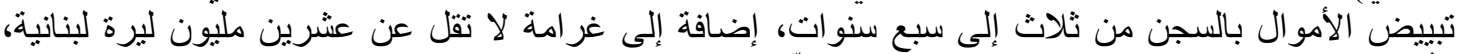

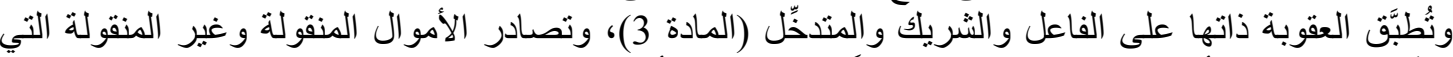

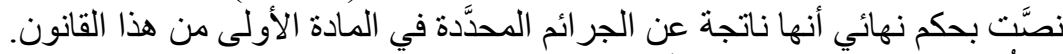

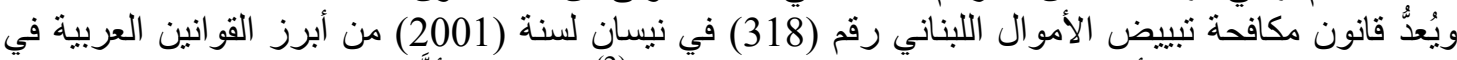

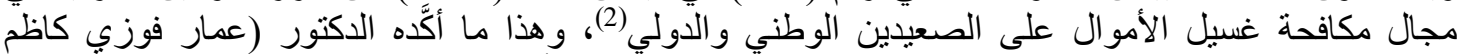

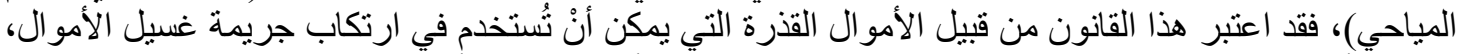

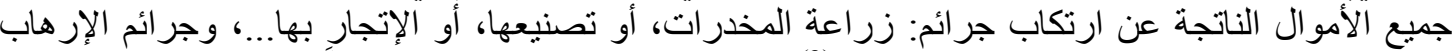

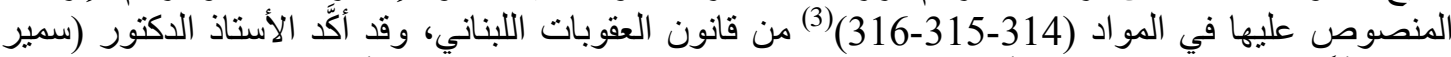

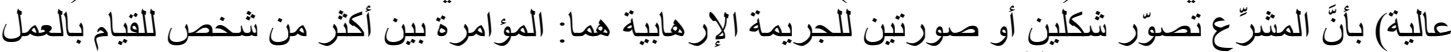

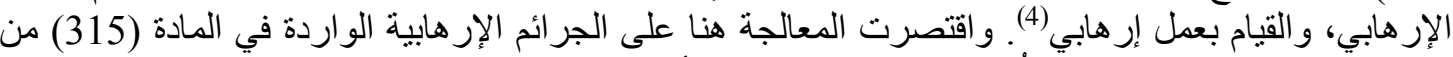

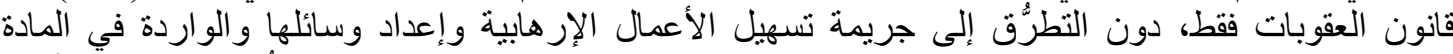

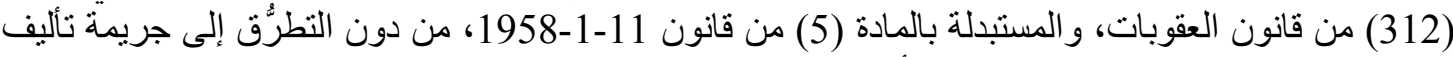

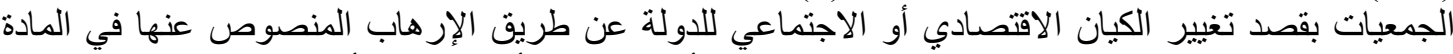

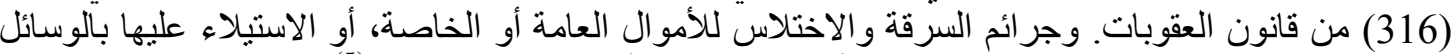

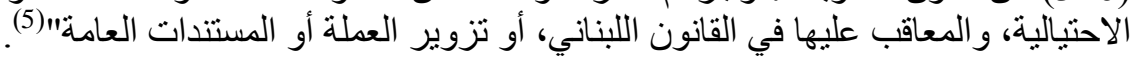

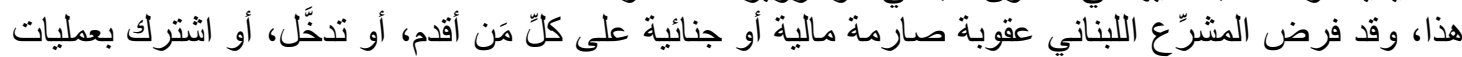

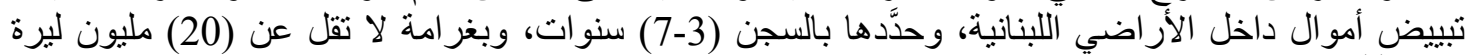

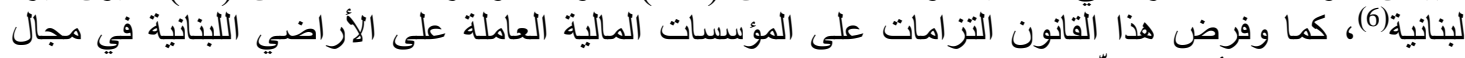

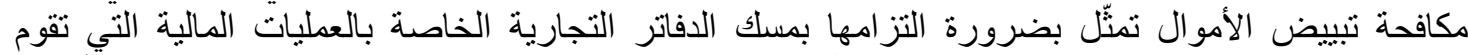

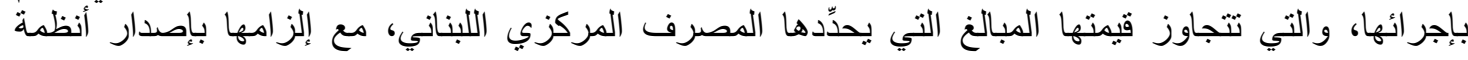

(1) ينظر : قانون رقم 318- في 20 نبسان 2001 (قانون مكافحة تبييض الأموال اللبناني).

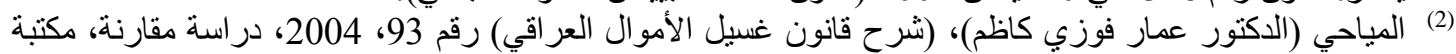

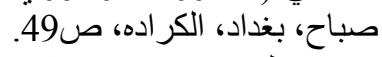

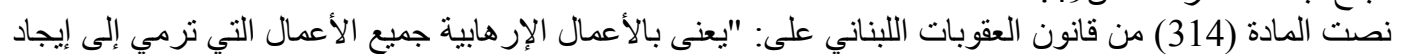

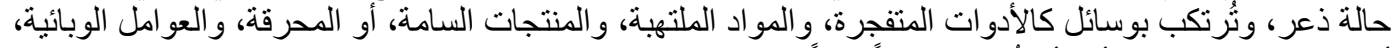

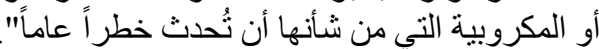

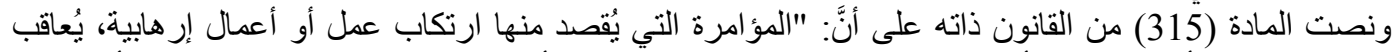

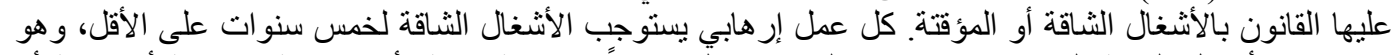

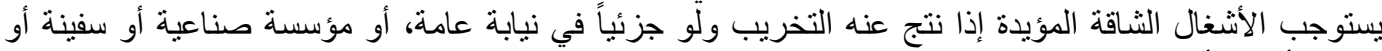

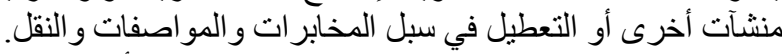

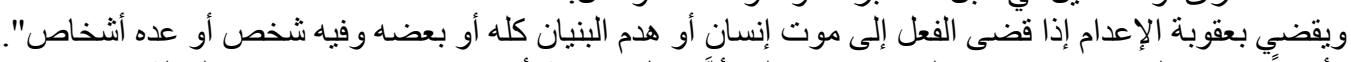

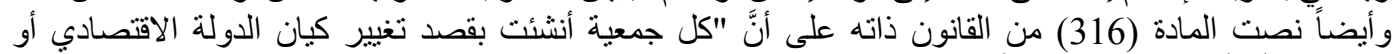

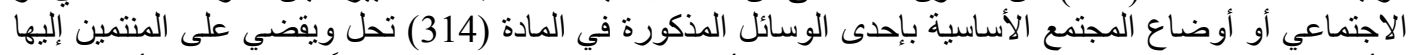

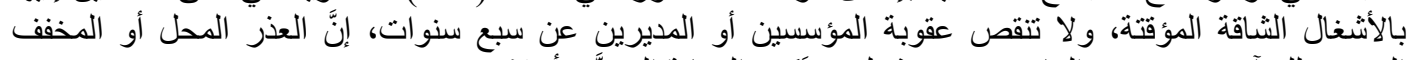

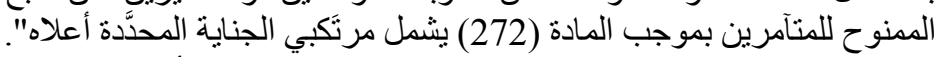

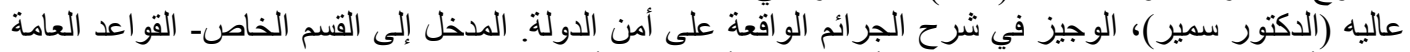

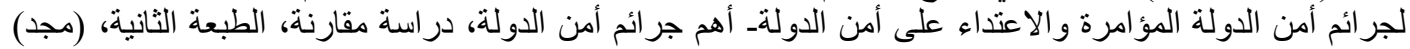

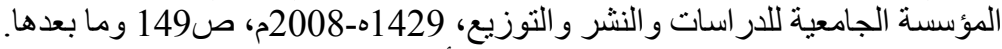
ينظر : المادة (15) من قانون مكافحة تبييض الأمو ال اللبناني النافذ رقم (318) للينة 2001. (6) - ينظر : المادة (3) من القانون ذاته. 
International Journal on Humanities and Social Sciences

website:www.ijohss.com

Email:editor@ijohss.com

ISSN: $2415-4822$

العدد(22) بوليو 2021

Volume (22) July 2021

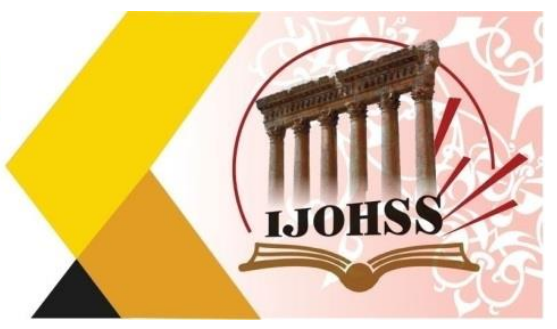

تتضمَّن التحقُق من هوية الزبائن لايها وعناوينهم، بالاستناد إلى الوثائق الرسمية المتعارف عليها قانوناً، مع

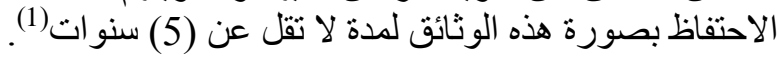

\section{المبحث الثاني

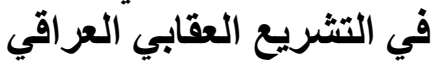

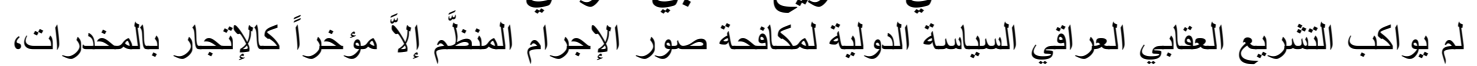

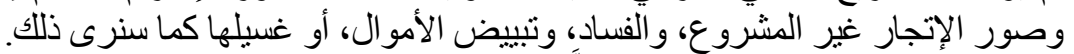

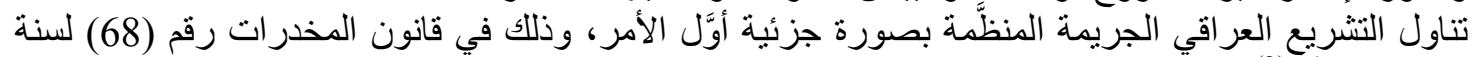

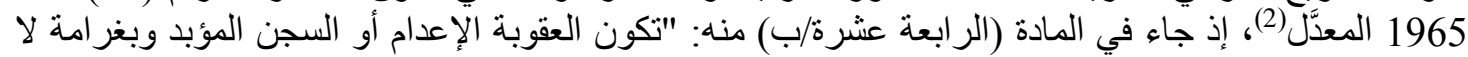

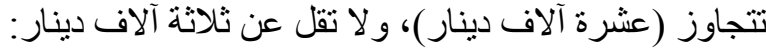

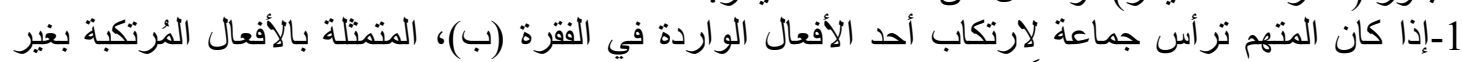

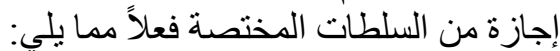

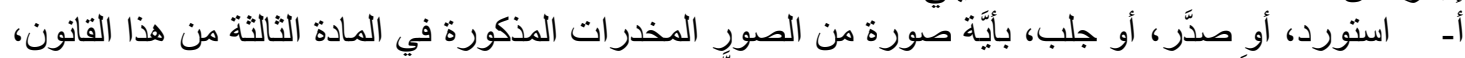

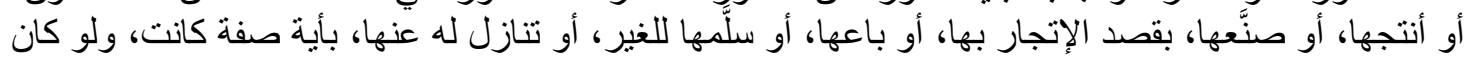

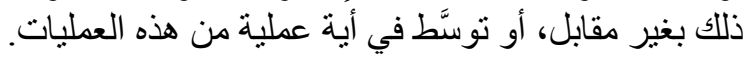

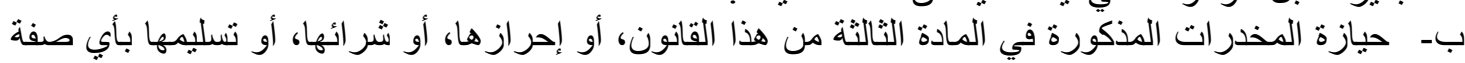
كانت الإتجار بها.

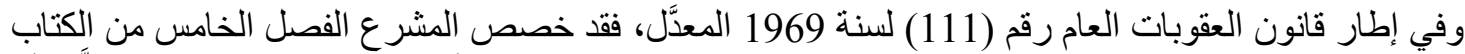

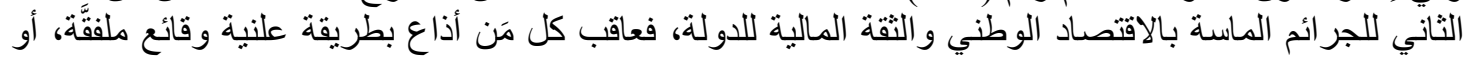

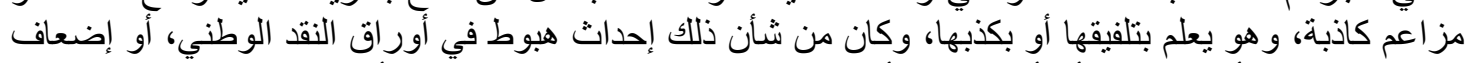

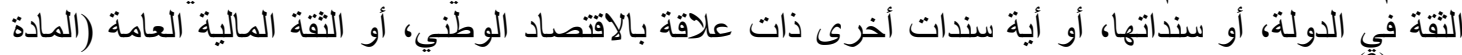

(3) $(304$

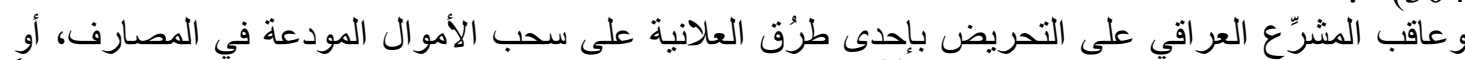

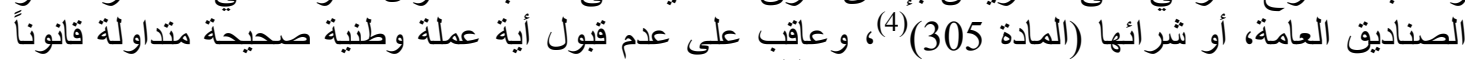

بقيمتها الإسمية معدنية كانت أم ورقية (المادة 306) (1) (1)،

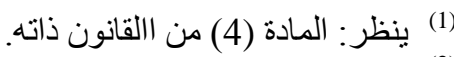

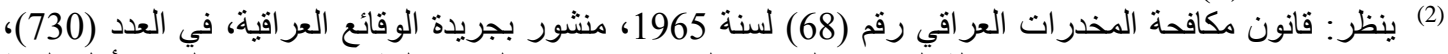

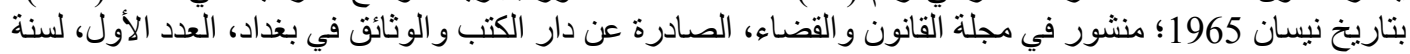

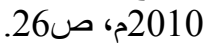

نصت المادة (304) من قانون العقوبات العراقي رقم 111 لسنة 1969/الباب الخامس/ الفصل الخامس/ الجرائم

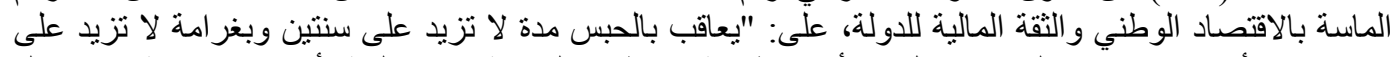

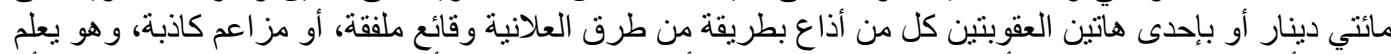

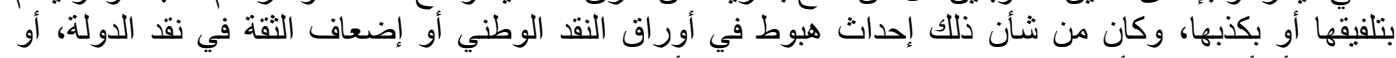

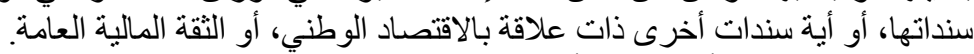

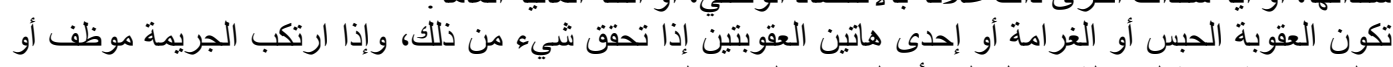

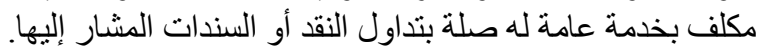
فإذا اجتمع هذا الظرفان المشددان، تكون عقوبة الموظف أو المكلف بالخدمة العامة السجن مدة لا نزيد على سبع

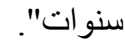

نصات المادة (305) من قانون العقوبات العراقي 111 لسنة 1969 الباب الخامس/ الفصل الخامس/ الجرائم الماسة

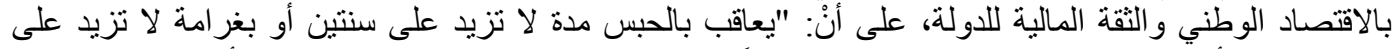

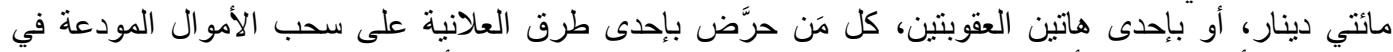

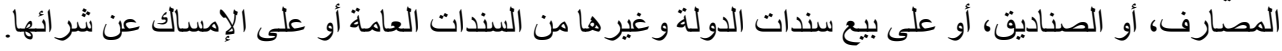

$=$ 
International Journal on Humanities and Social Sciences

website:www.ijohss.com

Email:editor@ijohss.com

يوليو 2021

العدد) (22)

ISSN: $2415-4822$

Volume (22) July 2021

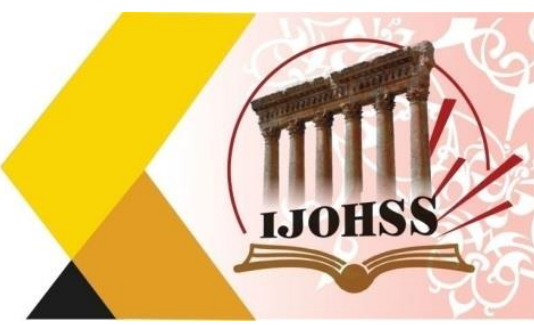

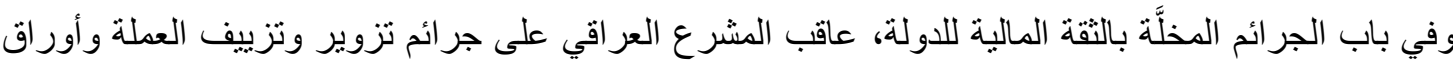

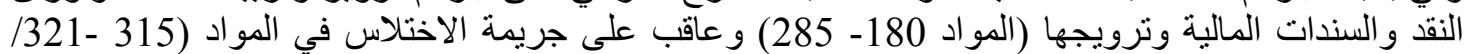

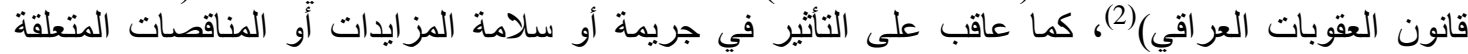

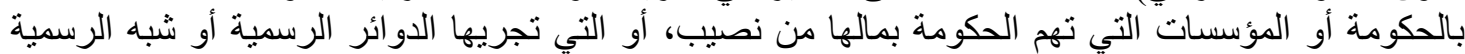

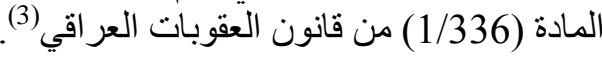

وتكون العقوبة الحبس و الغر امة أو إحدى هاتين العقوبتين، إذا ارتكب الجريمة موظف، أو مكلف بخدمة عامة له صلة بتداول النقد، أو السندات المشار إليها".

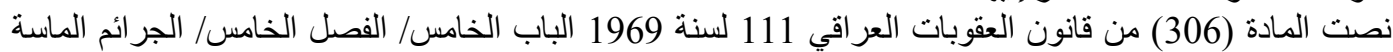

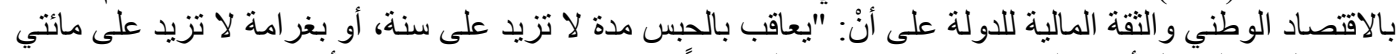

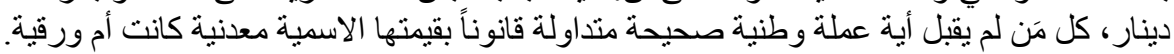

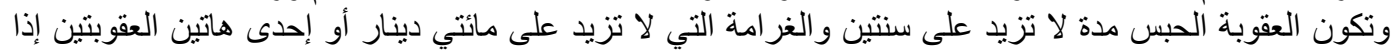

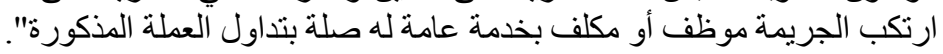

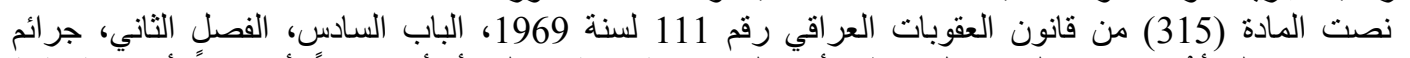

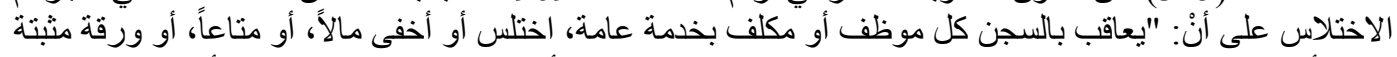

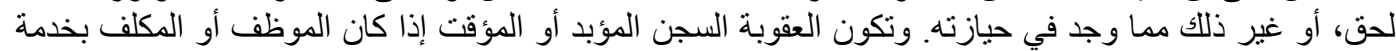

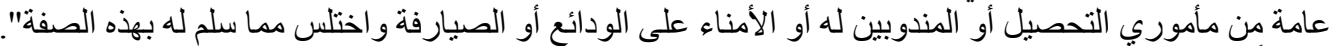

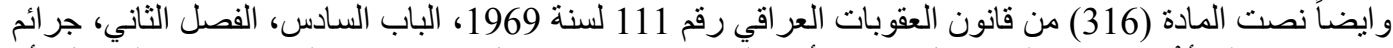

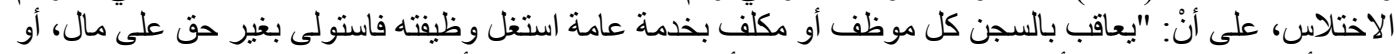

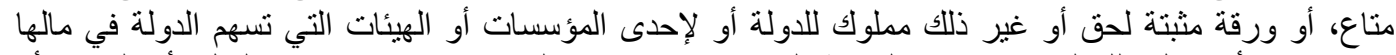

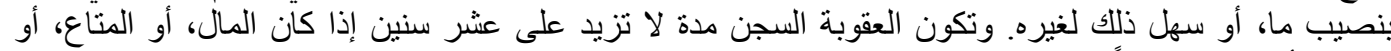

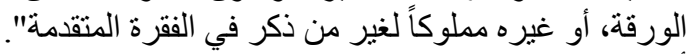

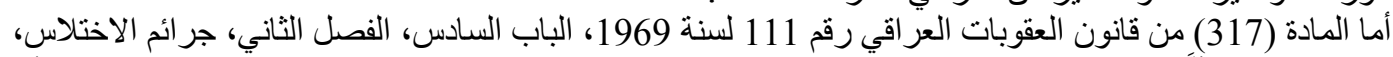

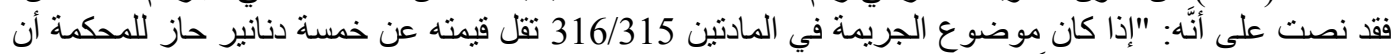

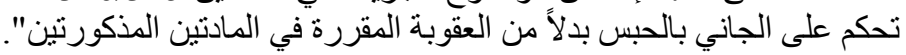

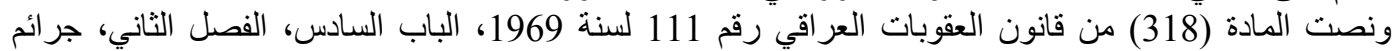

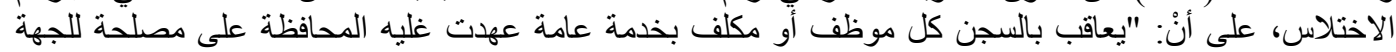

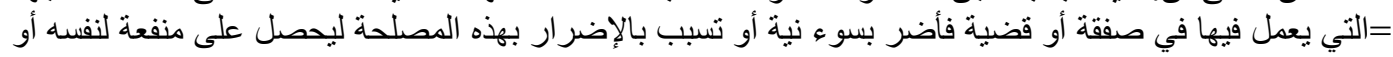
لغيره".

ونصت المادة (319) من قانون العقوبات العر اقي رقم 111 لسنة 1969، الباب السادس، الفصل الثاني، جرائم

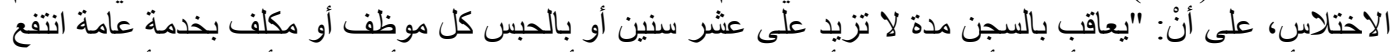

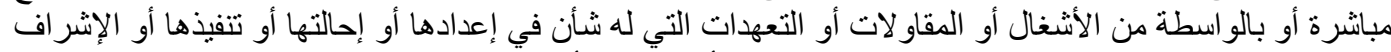

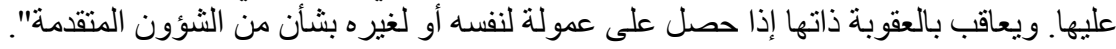

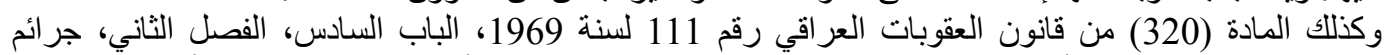

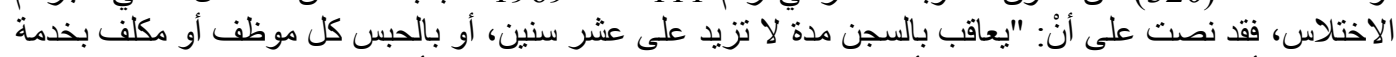

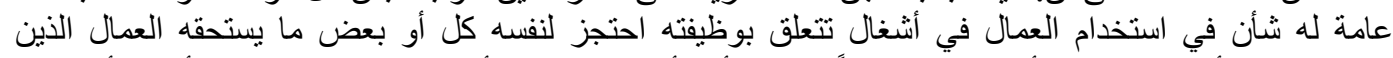

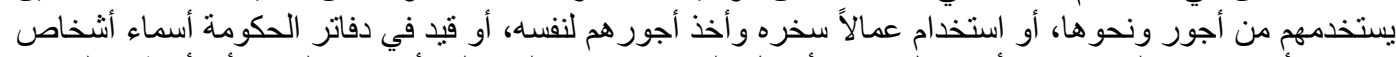

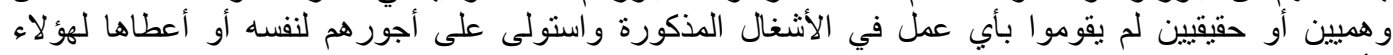

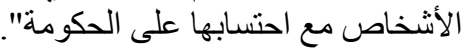

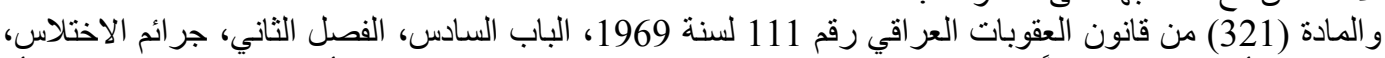

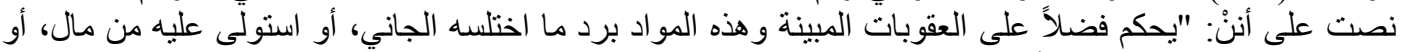
قيمة ما حصل عليه من منفعة أو ربح".

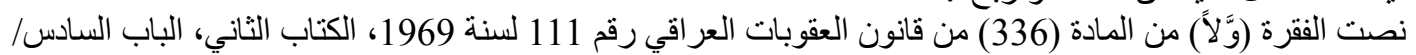

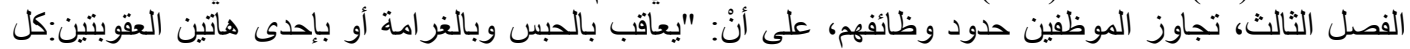
موظف أو مكلف بخدمة عامة أخل بطريقة الغش، أو بأية وسيلة أخرى غير مشروعة بحرية، أو سلامة المز ايدات، أو الو الئرئ $=$ 
International Journal on Humanities and Social Sciences

website:www.ijohss.com

Email:editor@ijohss.com

العدد(22) يوليو 2021

ISSN: $2415-4822$

Volume (22) July 2021

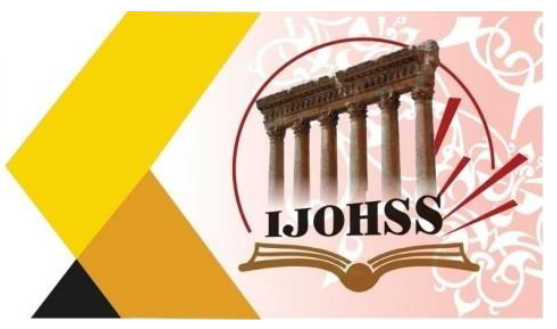

وتُعتبر جر ائم الأعمال المالية أو التجارية من جر ائم الغش في المعاملات التجارية (المادة 466) وجر ائم الإفلاس

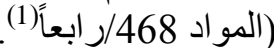

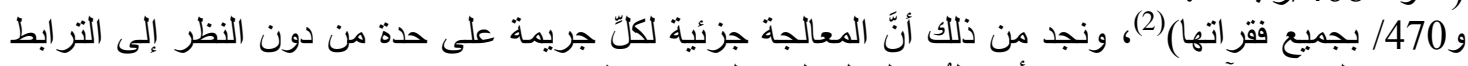

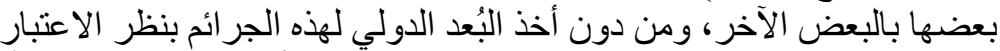

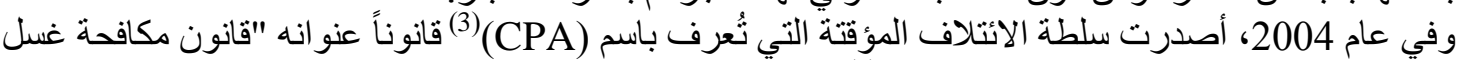

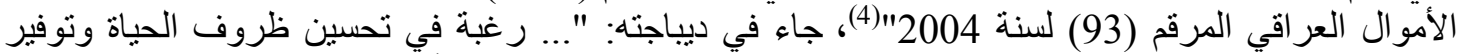

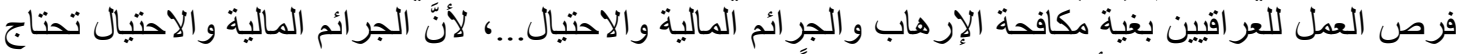

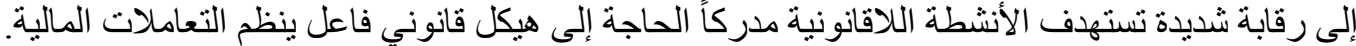

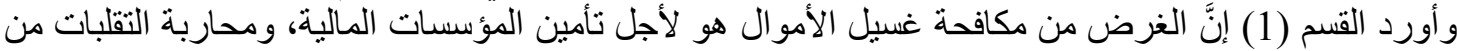

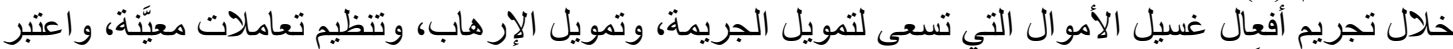

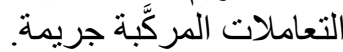
وقد تناولت المادة الثالثة من هذا القانون (قانون مكافحة غسيل الأمو ال العر اقي) رقم (93) لسنة 2004(5) و عرَّفته

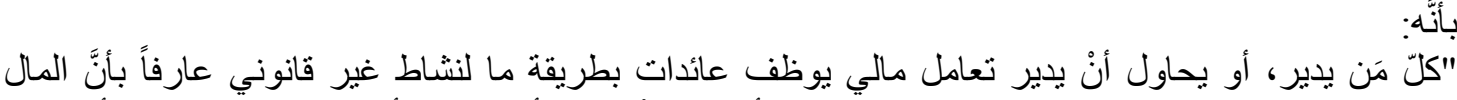

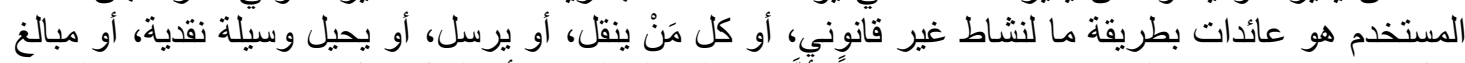

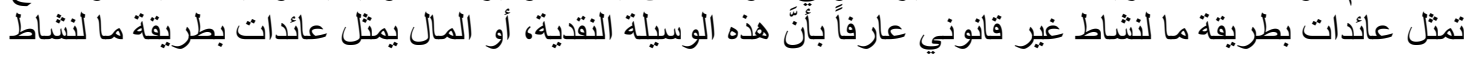

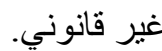
أـ مع نية المساعدة على تنفيذ نشاط غير قانوني، أوناني، الاستفادة من نشاط غير قانوني، أو لحماية الذين يديرون

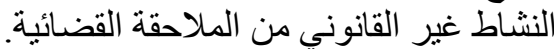

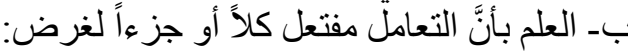

المناقضات المنعلقة بالحكومة، أو المؤسسات أو الثركات التي تسهم الحكومة بمالها بنصيب، أو تجريها الدوائر

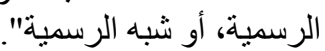

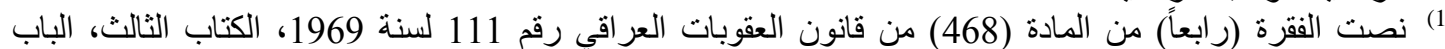

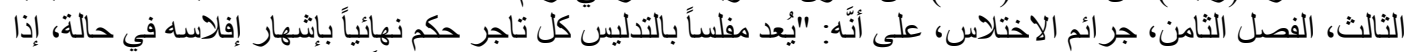

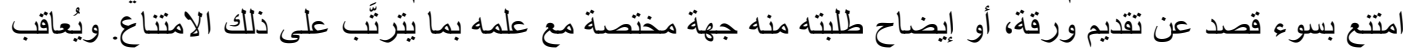

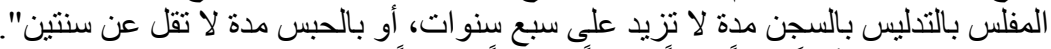

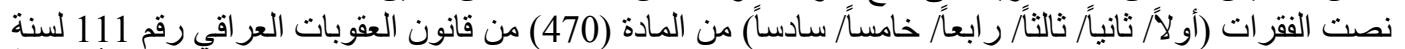

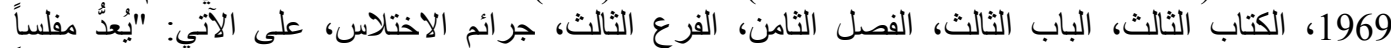

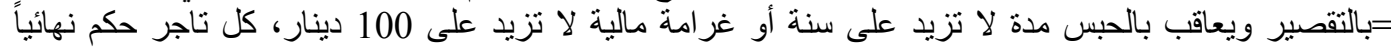
بإنشهار إفلاسه إذا تو افرت إحدى الحالات التاليكاتية:

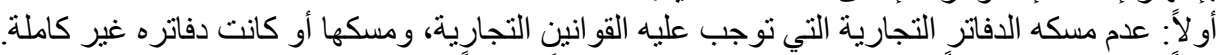

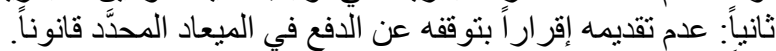

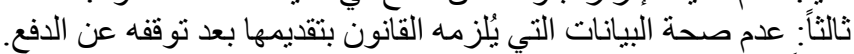

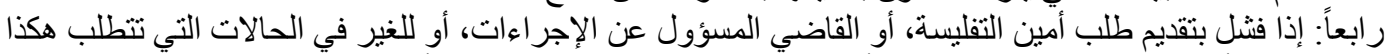

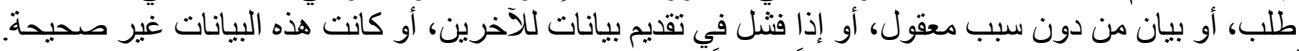

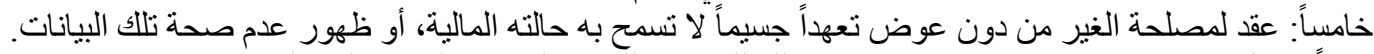

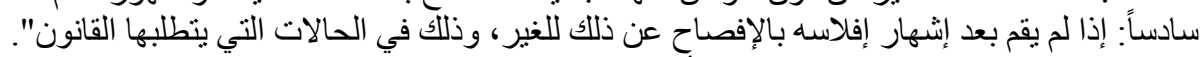

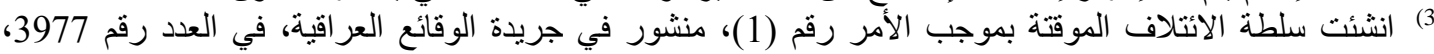
بتاريخ 23 ايار 2003. ينظر : قانون مكافحة غسيل الأمو ال العر اقي رقم (93) لسنة 2004، منشور في جريدة الوقائع العر اقية، في العدد رقم

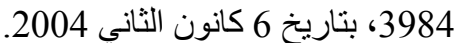
(5) ينظر : القسم الأوَّل (المادة 3) من قانون مكافحة غسيل الأموال العر اقي رقم 93 لسنة 2004. 
International Journal on Humanities and Social Sciences

website:www.ijohss.com

Email:editor@ijohss.com

يوليو 2021

العدد) (22)

ISSN: $2415-4822$

Volume (22) July 2021

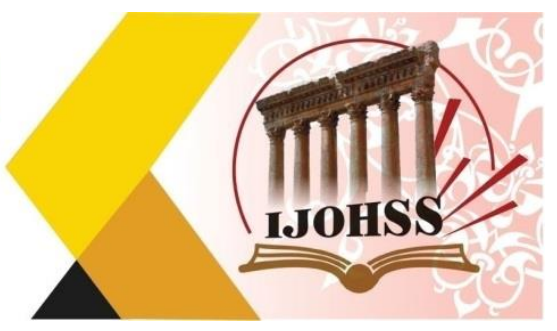

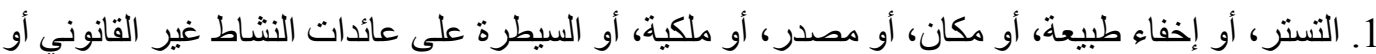

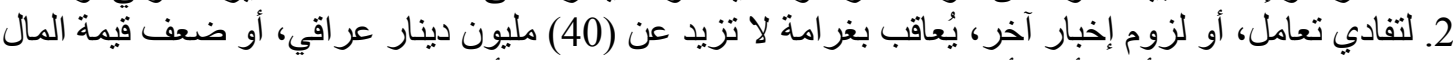

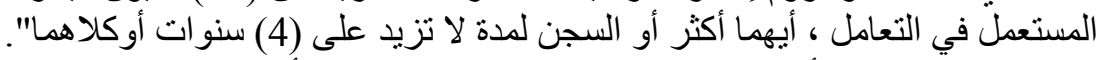

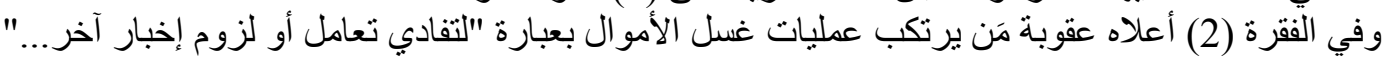
"يعاقب بغر امة لا تزيد عن 40 مليون دينار عراقي، أو ضعف قيمة المال المستعمل في التعامل أيهما أكثر، بأن:

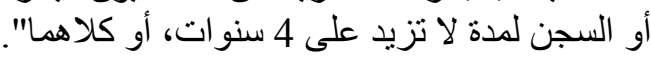

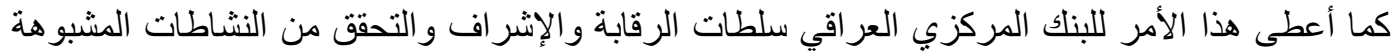

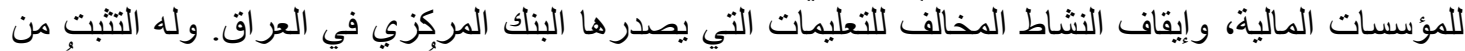

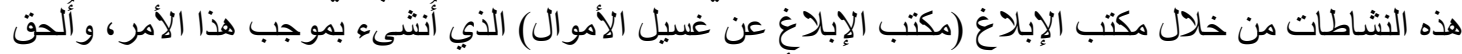

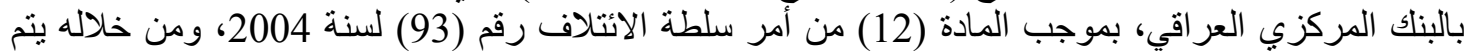
إعلام سلطات الملاحقة القضائية عن كل الإجراءات العرات المتعلقة بالنشاطات الموقوفة الإنة وفق هذا القانون، ومنها ما

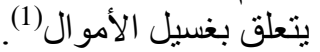
وقد صادق العراق مؤخراً على اتفاقية الأمم المتحدة لمكافحة الفساد التي انضمت إليها جمهورية العراق

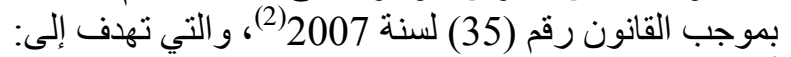

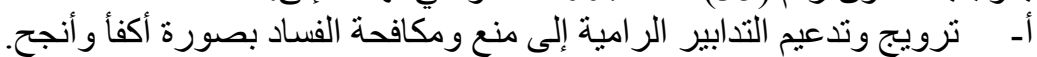
بــ ترويج وتيسير ودعم التعاون الدولي، و المساعدة التقنية في مجال منع ومكافحة الفساد، بما في ذللك استرداد

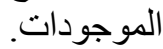

ج-تعزيز النز اهة و المساءلة و الإدارة السليمة للثؤون العمومية و الممتلكات العمومية.

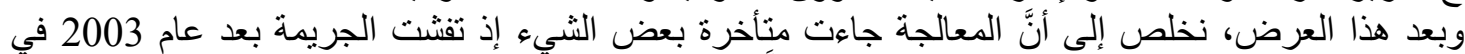

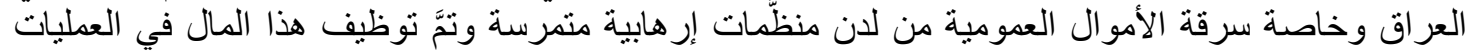

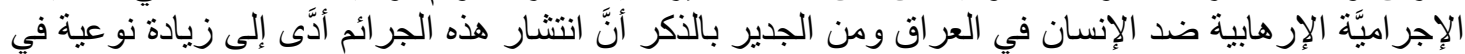

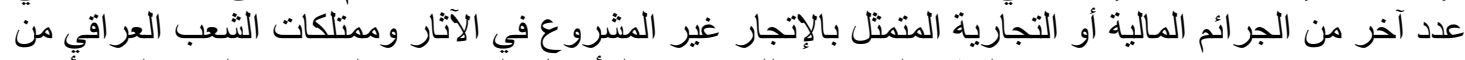

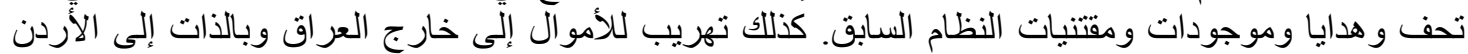

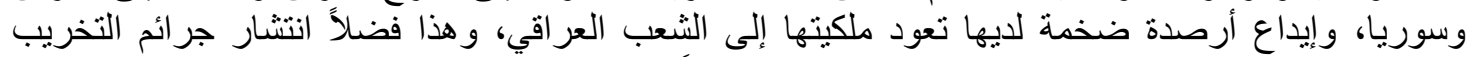

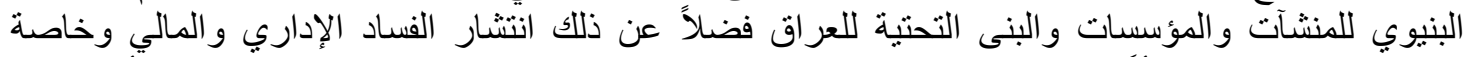

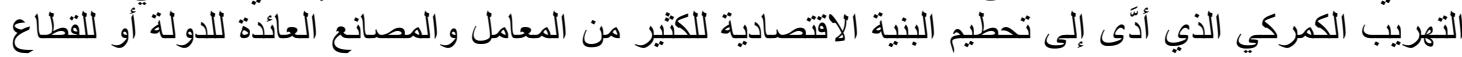

(1) ينظر : القسم الثالث ـ المواد (7) إلى ( 13) من قانئ فانون مكافحة غسيل الأموال العرافي رقم (93) لسنة 2004 المنشور

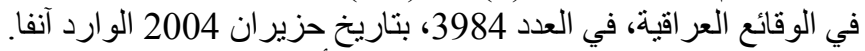

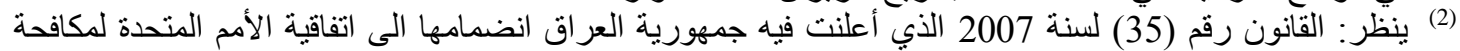

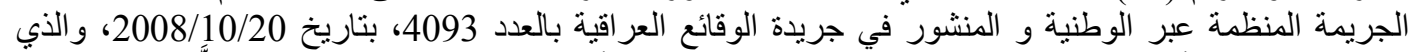

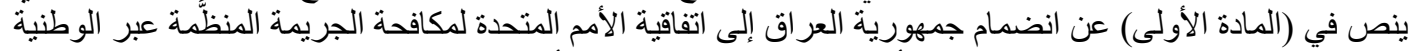

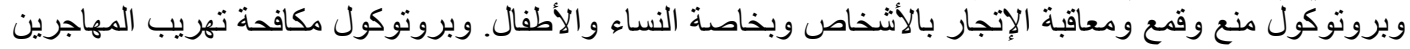

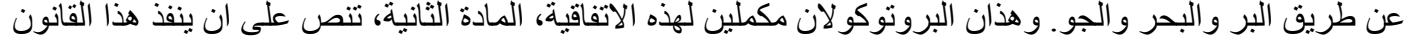




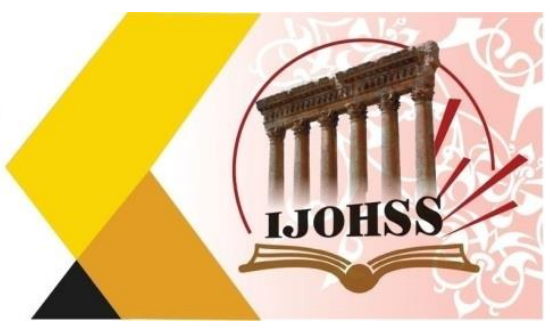

الخاتمــة

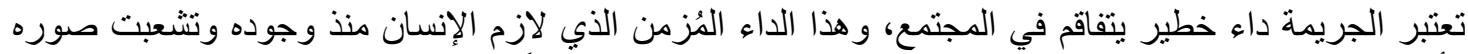

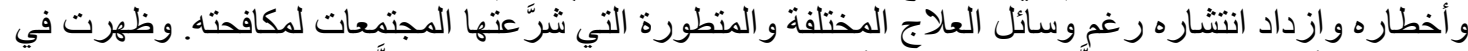

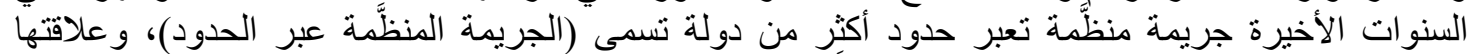

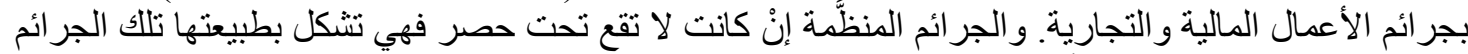

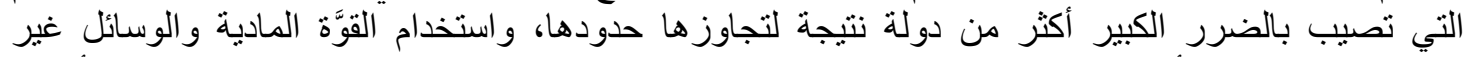

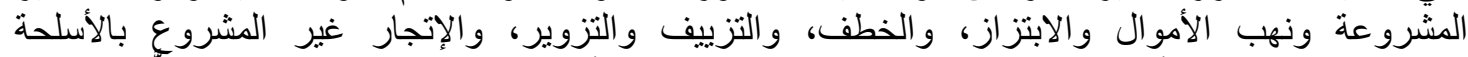

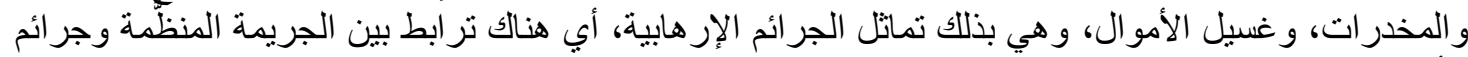

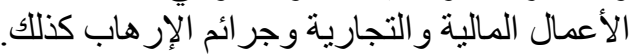

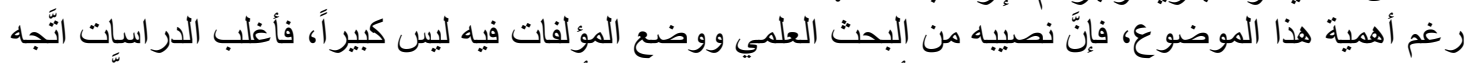

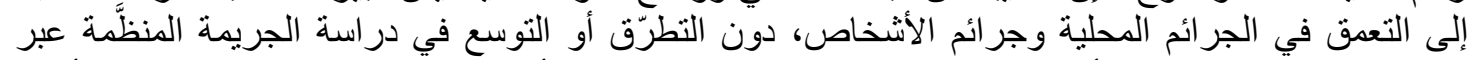

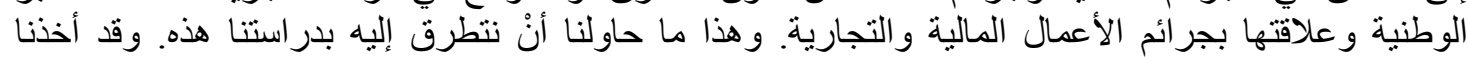

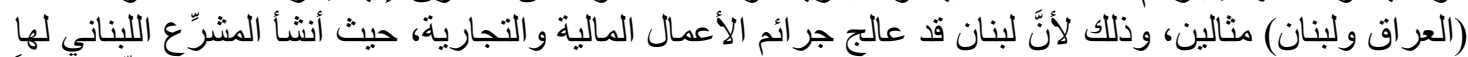

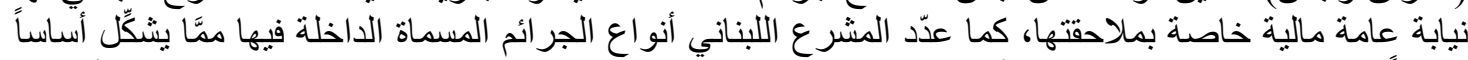

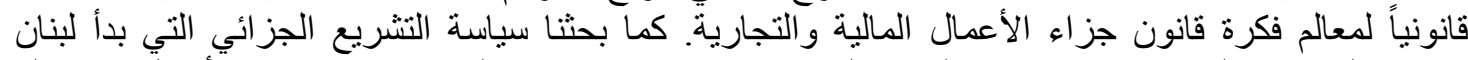

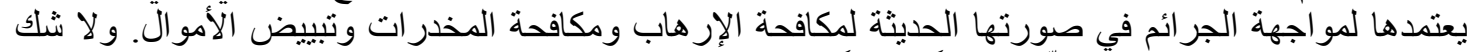

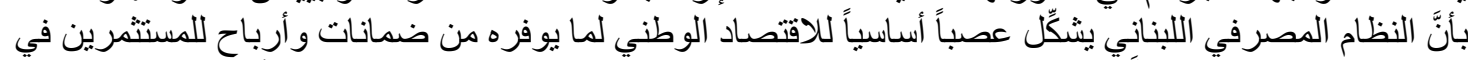

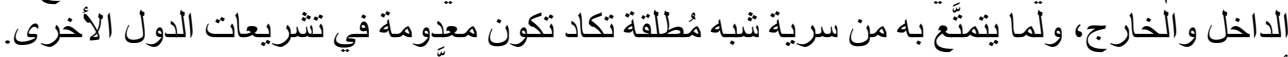

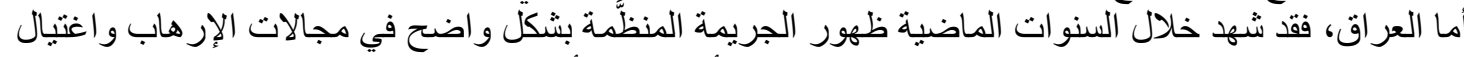

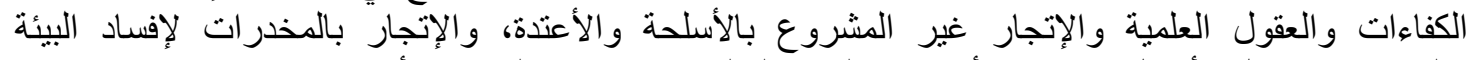

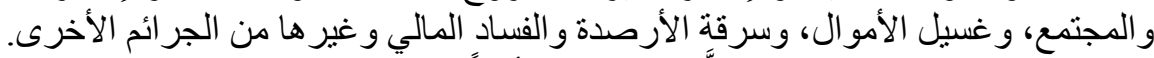

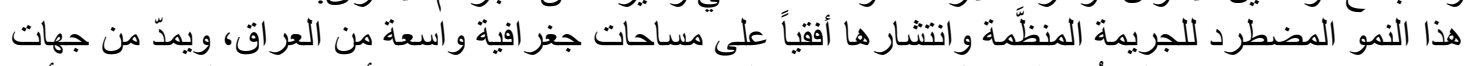

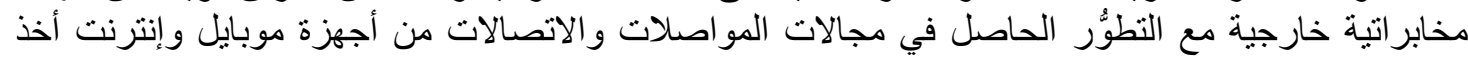

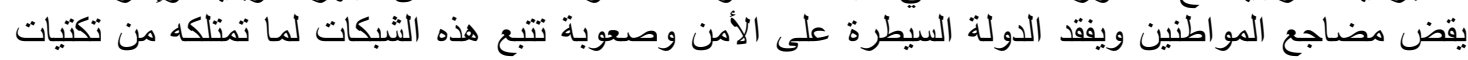

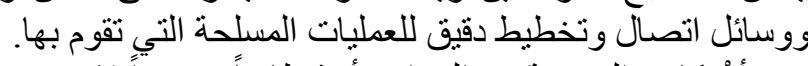

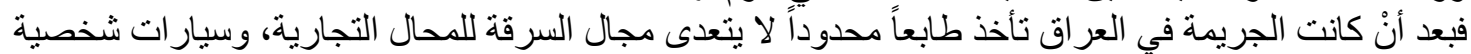

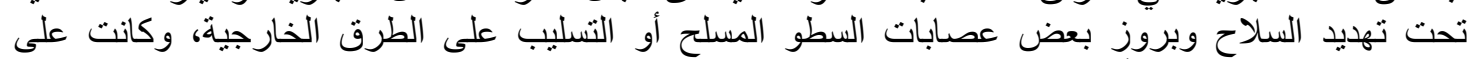

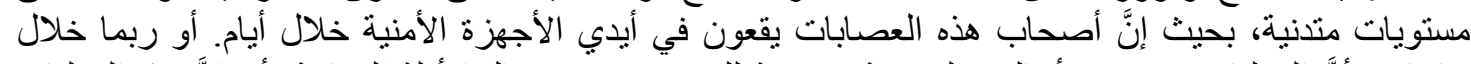

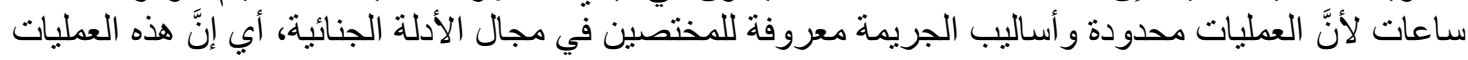

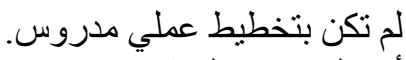

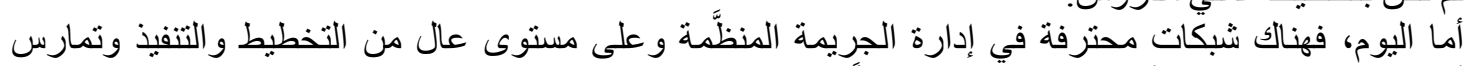

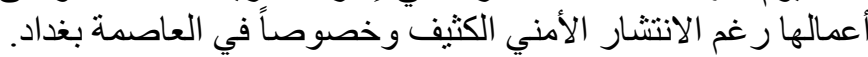

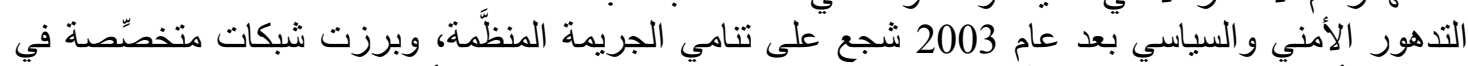

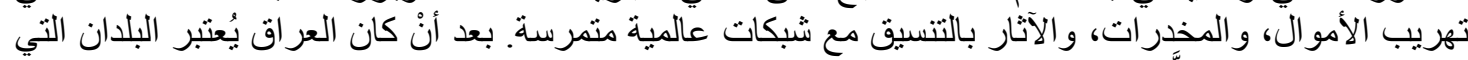
لا لاوجود للجريمة المنظمَّة فيه.

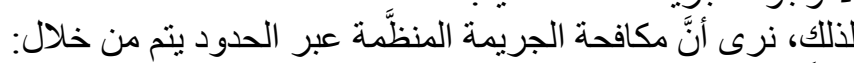

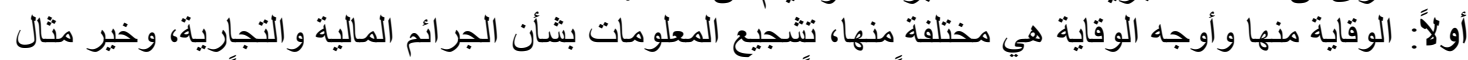

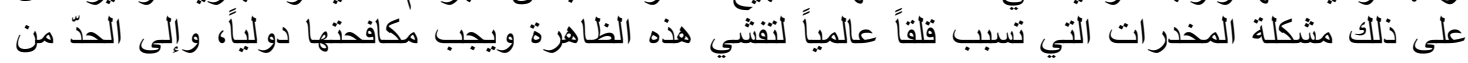

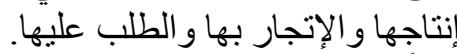

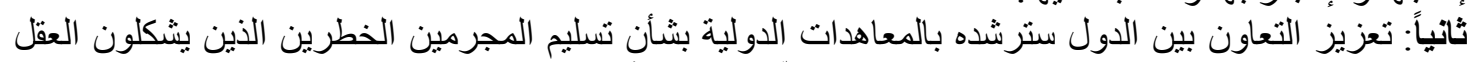

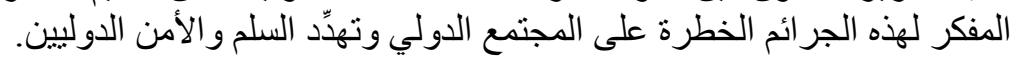




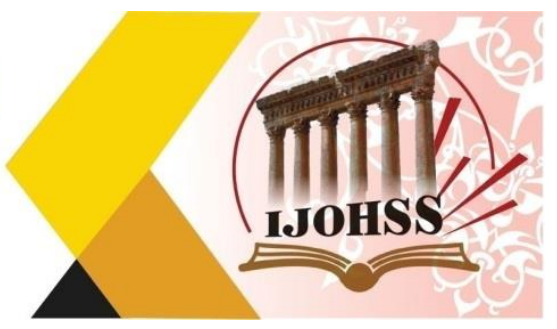

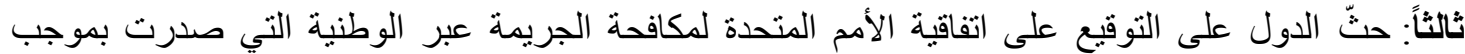

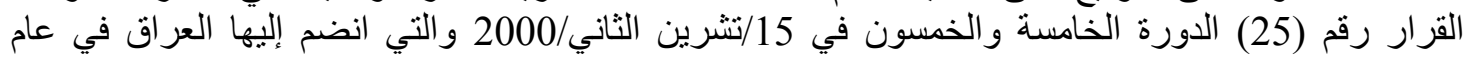

2007.

رابعاً: تشجيع الدول على إصدار قوانين لمكافحة غسيل الأمو ال ومكافحة المخدرات. كما سار في ذلك لبنان

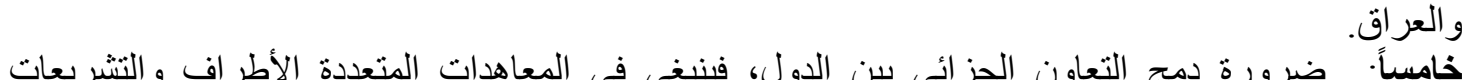

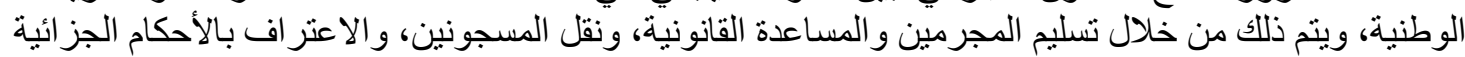
الأجنبية، وكذلك تنفيذ القو انين، و التعاون بين المناك المحاكم.

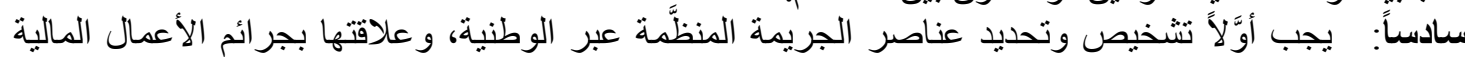

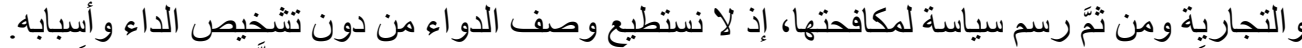

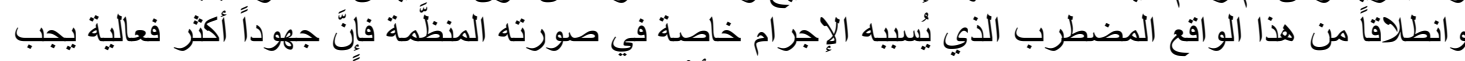

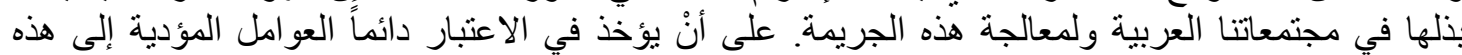

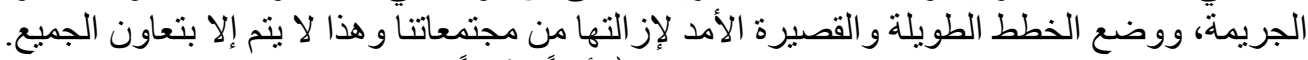

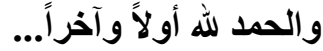

1- الدكتور أحمد عبد الخالق، الآثار الاقتصادية والاجتماعية لغسيل الأموال، الطبعة الأولى، دار النهضة

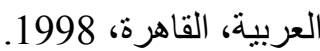

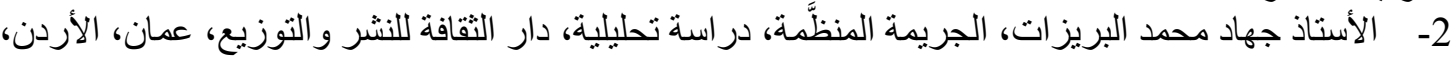

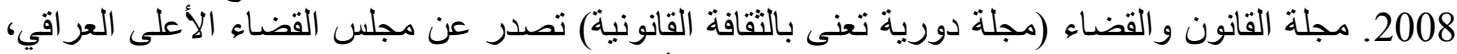

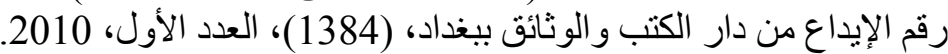

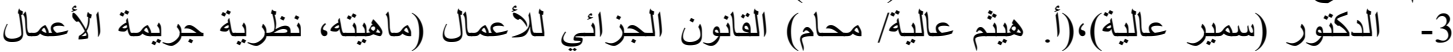

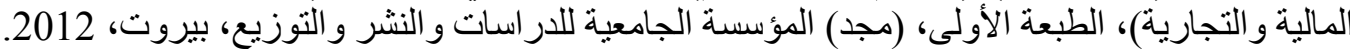

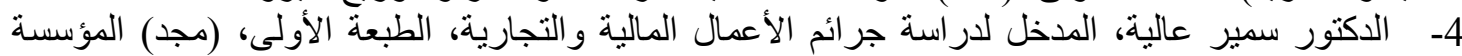

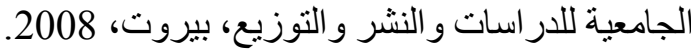

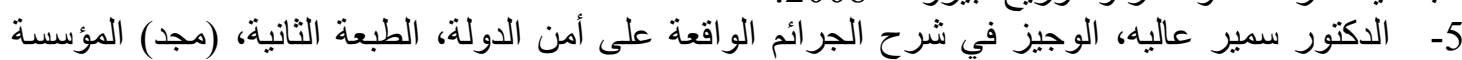

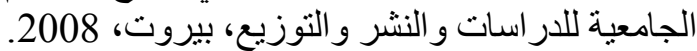

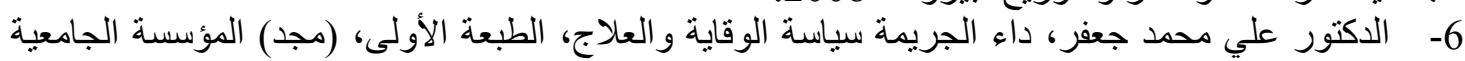
للار اسات و النشر وَ التوزيع، بيروت،

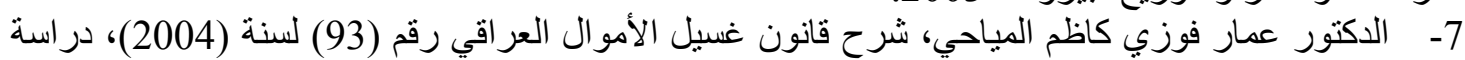

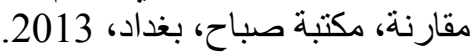

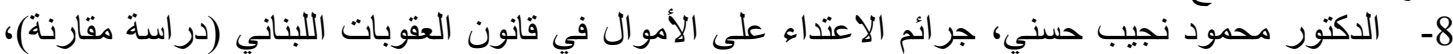

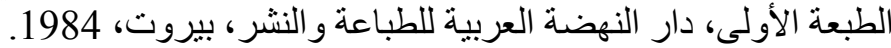

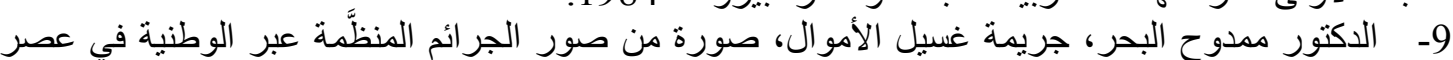

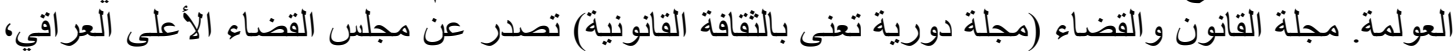

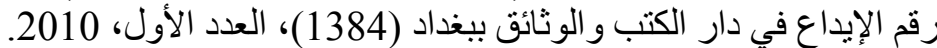

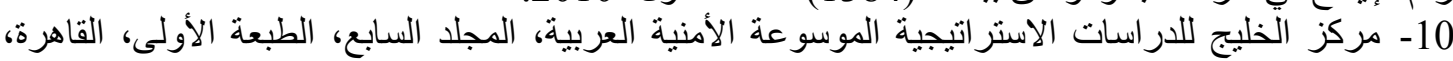



International Journal on Humanities and Social Sciences website:www.ijohss.com

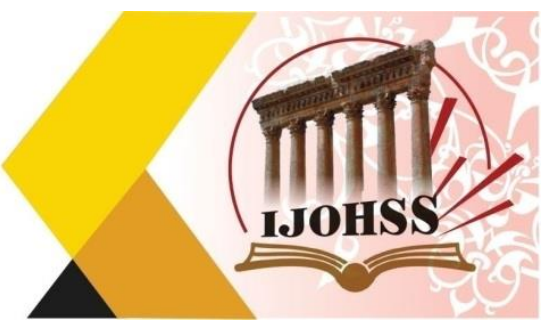

ثُانياً: القوانين والاتفاقيات

1- قانون مكافحة المخدرات العر اقئ اقي رقم (68) لسنة 1965 المنشور في جريدة الوقائع العراقية الرسمية في

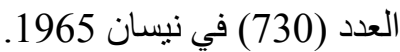

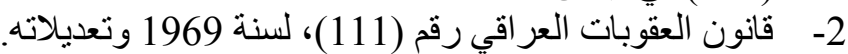

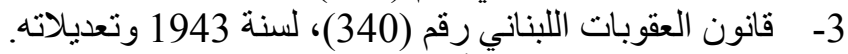

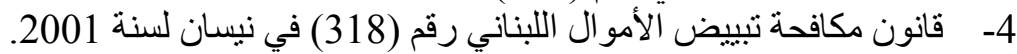

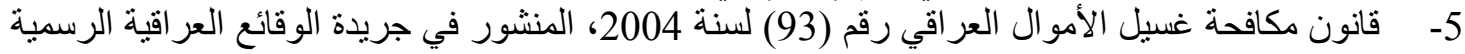

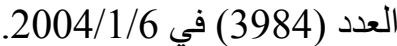

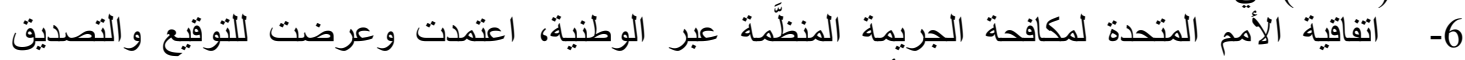
و الانضمام بموجب قرار الجمعية العامة للأمم المتحدة رقم (25) الدورة (الخامسة والخمسون) في 15/تشرين الثاني/2000. 